\title{
SYCLE ONE SCHOOL PRINCIPLES'TEACHER JOB SATISFACTION IN NORTH AL BATINAH IN THE SULTANATE OF OMAN
}

\author{
Mohammed Saleh ALAJMI ${ }^{1}$ \\ Naima Salim Said AL RISI ${ }^{2}$
}

\section{Istanbul / Türkiye \\ p. 503-527}

\section{Received: 04/12/2021 \\ Accepted: $17 / 12 / 2021$ \\ Published: 01/01/2022}

This article has been scanned I iThenticat No plagiarism detected

\begin{abstract}
:
The study aimed to identify the leadership patterns practiced by the female principals of the first circle schools as seen by the teachers of the first field in the province of North Al Batina, and to identify the level of job satisfaction of the teachers of the first field, and to reveal the correlation between the leadership patterns of the female principals of the first circle and the job satisfaction of the teachers of the first field. The researcher used the descriptive correlation method, and designed two questionnaires: the questionnaire measuring the leadership patterns of the female school principals of the first episode in North Al-Batina, and the other the questionnaire of the measurement of job satisfaction in the teachers of the first field in The North Al-Batina, each questionnaire contained 30 paragraphs, and included three axes. The results of the study showed that the democratic leadership style came first, with a mathematical average of 4.45 , which is the most practiced pattern among the principals of the first circle schools in the province of North Al-Batina, followed by the autocratic leadership pattern, the leadership pattern, asindicated by the results of the study to the high level of job satisfaction in all axes with a mathematical average of 4.52 , and came first the center of job satisfaction related to satisfaction with the nature of work, with a mathematical average of 4.62 , followed by the axis of satisfaction of school mates, and came in third place the focus of satisfaction for the school principal, and also indicated the results of the study indicated the existence of a positive medium statistically function between the practice of the female principals of the first circle schools in the province of North Al-Batina of the democratic leadership style and the job satisfaction of the teachers of the first field, where the correlation reached the coefficient $r=0.61$. Based on the results of the current study, the researcher recommends: maintaining the level of active practice of the democratic leadership style of the female teachers of the first circle schools in North Al-Batina, because of its importance in achieving a good level of job satisfaction, and maintaining the level of high job satisfaction among the teachers of the first field in North Al-Batina, because of its role in achieving.
\end{abstract}

Key words: Principles, School, Job Satisfaction.

http://dx.doi.org/10.47832/2717-8293.15.36

1 iD Dr., Suhar University, Sultanate of Oman, majmi3@su.edu.om, https://orcid.org/0000-0002-6882-7608

2 (iD) Researcher, The Ministry of Education, Sultanate of Oman, Naema526@ moe.om, https://orcid.org/0000-0002-8174$\underline{3257}$

Copyright (C) Published by Rimak Journal, www.rimakjournal.com Rimar Academy, Fatih, Istanbul, 34093 Turkey 


\section{الأنماط القيادية لمديرات مدارس الحلقة الأولى بمحافظة شمال الباطنة في سلطنة عمان وعلاقتها بالرضا الوظيفي لمعلمات الجمال الأول}

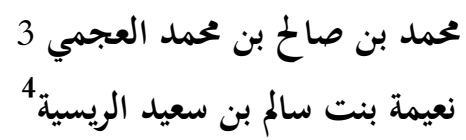

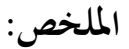
هدفت الدراسة إلى التعرف على الأنماط القيادية التي تمارسها مديرات مدارس الحلقة الأولى كما تراها معلمات المجال الأول في محافظة شمال الباطنة بسلطنة عمان، والتعرف على مستوى الرضا الوظيفي لمعلمات البمال الأول، والكشف عن العلاقة الارتباطية بين الأنماط القيادية لمديرات مدارس الحلقة الأولى والرضا الوظيفي لمعلمات المجال

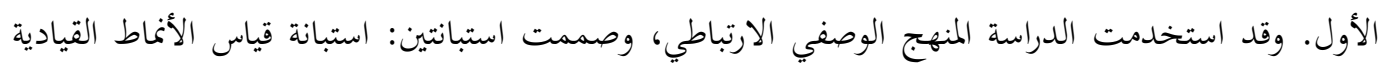

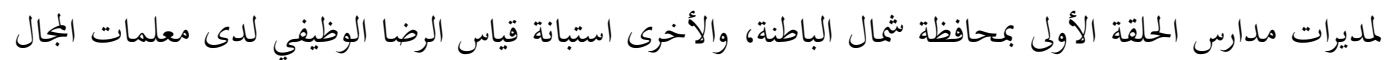

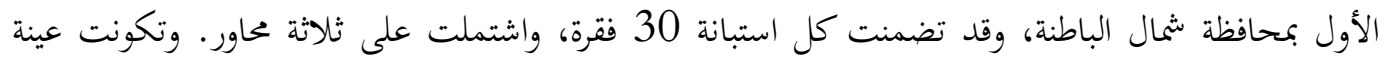

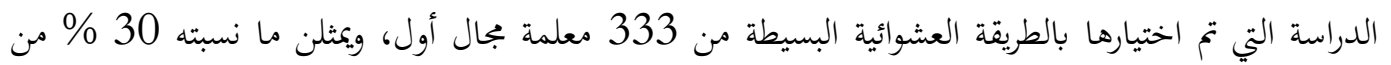

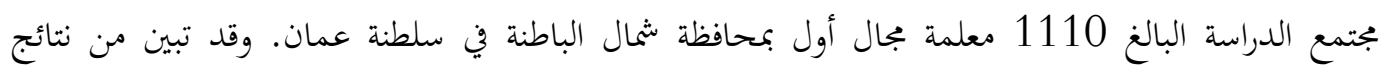
الدراسة أن النمط القيادي الديموقراطي جاء في المرتبة الأولى، بمتوسط حسابي مقداره فهو النمط الأكثر ممارسة لدى مديرات مدارس الحلقة الأولى في محافظة شمال الباطنة في سلطنة عمان، ثم تلاه النمط القيادي الأوتوقراطي بمتوسط حسابي مقداره 2.93، وبصفة ممارسة متوسطة، فالنمط القيادي الترسلي بمتوسط حسابي مقداره 2.64، وبصفة ممارسة متوسطة، كما أشارت نتائج الدراسة إلى ارتفاع مستوى الرضا الوظيفي في جميع المحاور بمتوسط حسابي مقداره 4.52، بصفة عالية جدا، وقد جاء في المرتبة الأولى محور الرضا

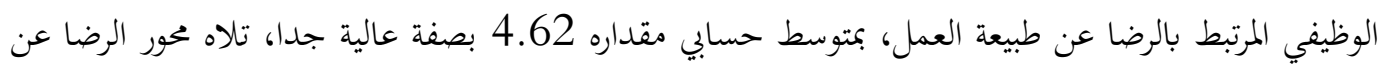
زميلات المدرسة بصفة عالية جدا، وجاء في المرتبة الثالثة محور الرضاعن مديرة المدرسة بمتوسط حسابي مقداره 4.37 بصفة عالية جدا. وأيضا أشارت نتائج الدراسة إلى وجود علاقة موجبة متوسطة دالة إحصائيا بين ممارسة مديرات مدارس الحلقة الأولى في محافظة شمال الباطنة للنمط القيادي الديموقراطي وبين الرضا الوظيفي لمعلمات

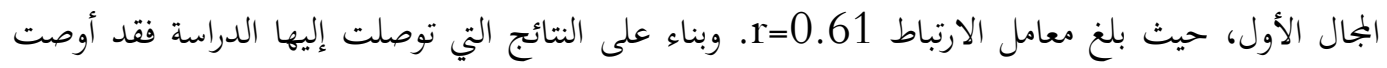
بالآتي: الحفاظ على مستوى ممارسة فاعلة للنمط القيادي الديمقراطي لدى مديرات مدارس الديأ الحلقة الأولى بمحافظة

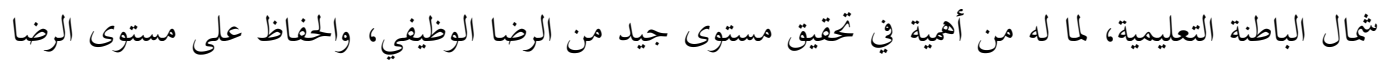

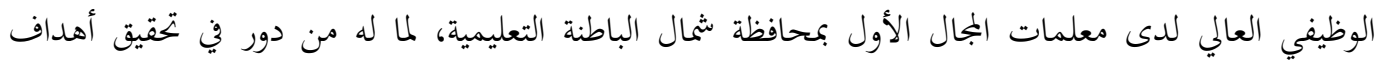
العملية التعليمية الكلمات المفتاحية: الأنماط القيادية، الرضا الوظيفي، التعليم. 
بدأ الاهتمام بالرضا الوظيفي مع بداية القرن العشرين، لأنه من العوامل الأساسية التي تساعد على تحقيق الازدهار في المجتمع المدرسي، فإذا توافرت الوسائل المادية والمعنوية اللازمة لإنجاز العمل، وتهيأت الظروف المناسبة في المدرسة كان المعلم أكثر لمان قدرة على الإنجاز والعطاء، لذلك فقد أصبح الرضا الوظيفي من أهم الموضوعات الإدارية التي تشغل خبراء الإدارة التربوية، كونه

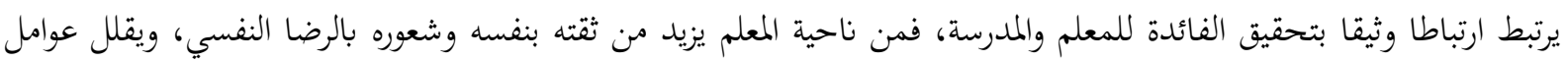

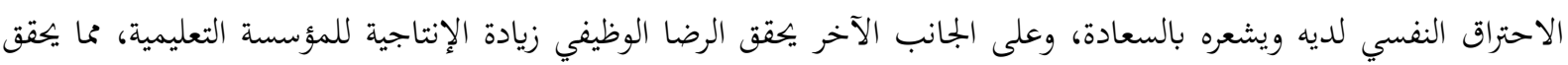

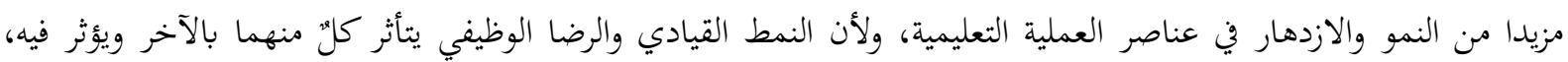
فالمناخ الذي يوفره النمط القيادي داخل بيئة العمل ينعكس على العاملين في المؤسسة ومدى تقبلهم لطبيعة العمل وزيادة الإنتاج،

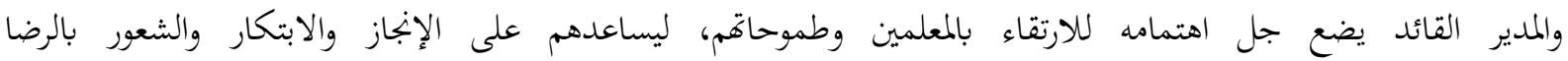

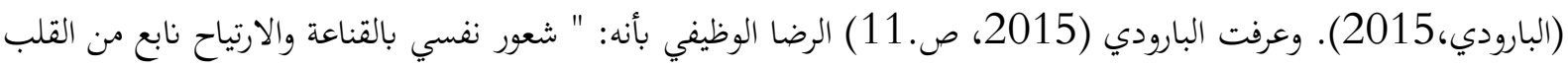

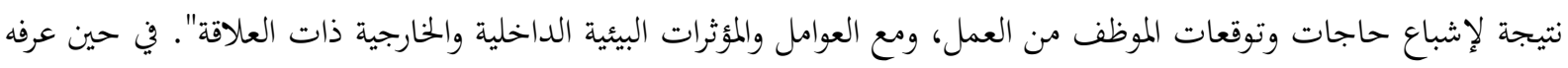

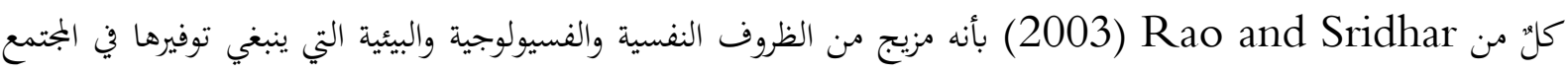
القيادي، والتي تجعل الشخص يقول أنا راض عن وظيفتي، فتجعله يقبل عليها برغبة. ويضيف Osbourne (2015) بأن

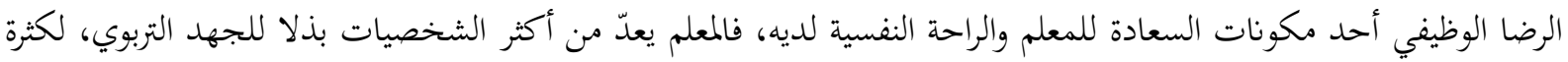

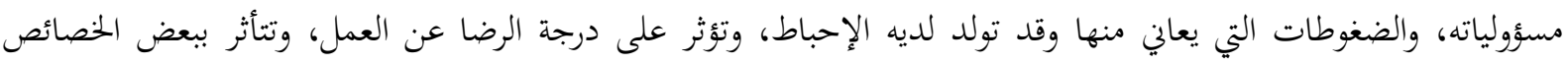

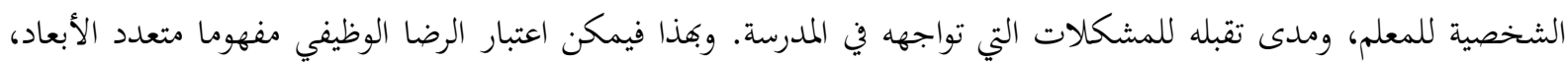

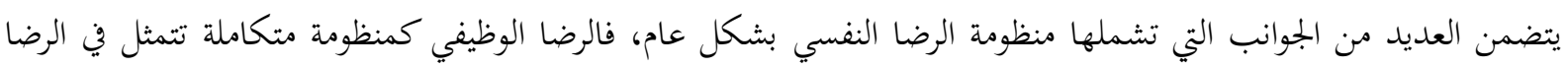

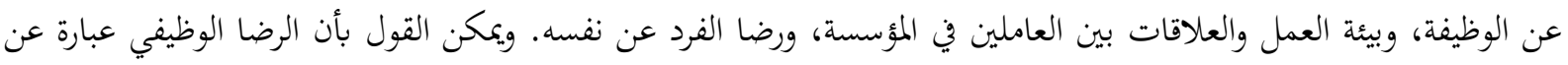
شعور بالراحة والسعادة في بيئة العمل، ويعبر عن رضا الفرد عن وظيفته ومديره وزملائه، ومتمثلا في الاحترام الذي يلقاه، وتقديره

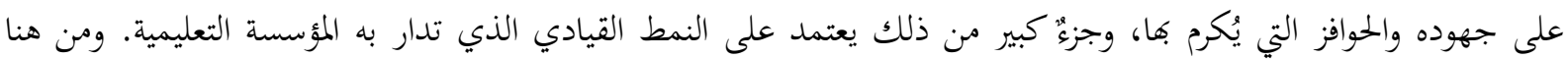

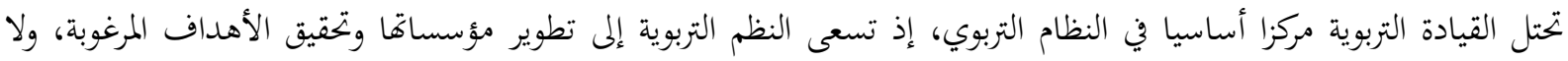

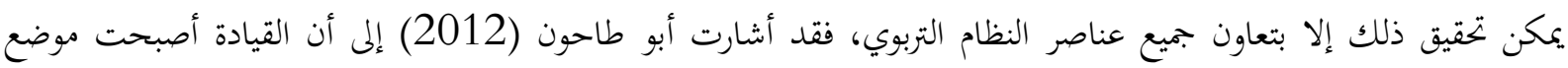

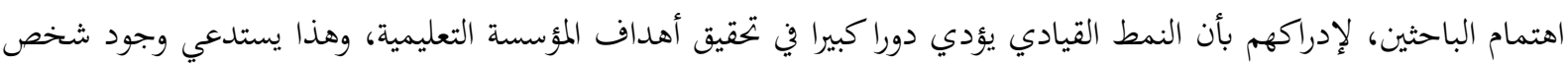
يتمتع بصفات القيادة الفاعلة، فالقيادة عملية يستطيع الفرد من خلالها التأثير على المجموعة لتحقيق الأهداف، والهي والقيام بالأعمال الموكلة إليهم بفاعلية. ويعتبر النمط القيادي الفاعل عنصرا مهما في تحقيق رسالة المؤسسة التعليمية ورؤيتها، لأن القائد ذو النمط

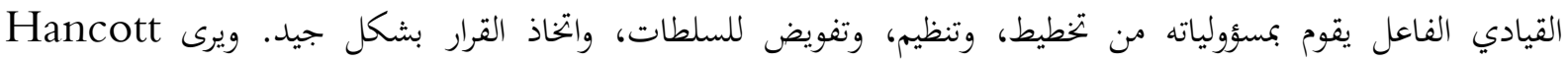

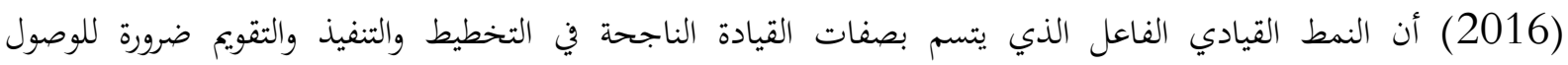

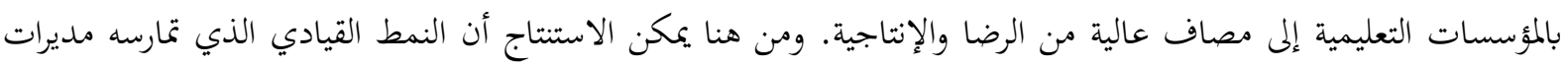

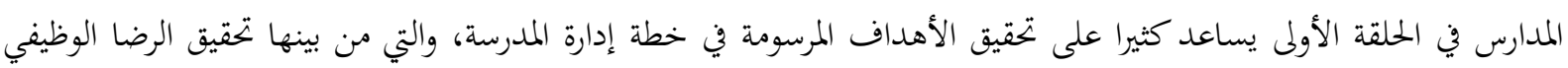
لجميع العاملين في المجتمع المدرسي، وبما يؤدي إلى تحقيق مخرجات تعليمية ذات مستويات جيدة في الأداء والتحصيل الدراسي.

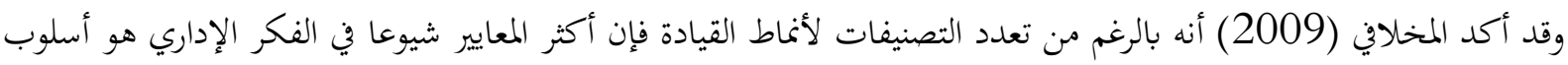

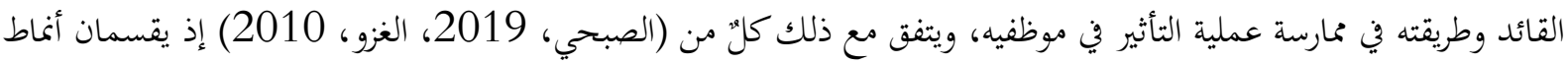

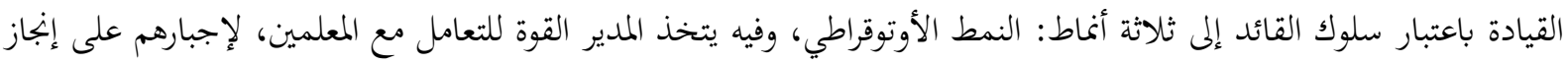

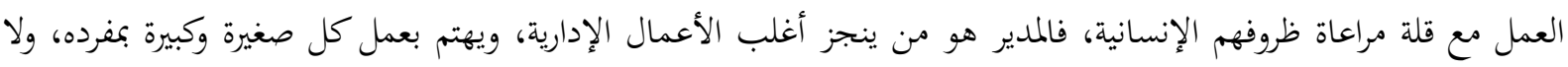


يلجأ للتفويض غالبا ولا يقبل بالآراء ولا يثق إلا بنفسه ولا يهتم بالعلاقات الإنسانية كثيرا، وينسب النجاح لنفسه غالبا، وهذه

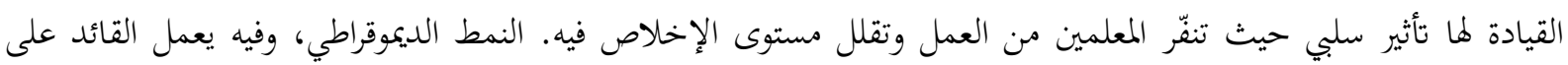

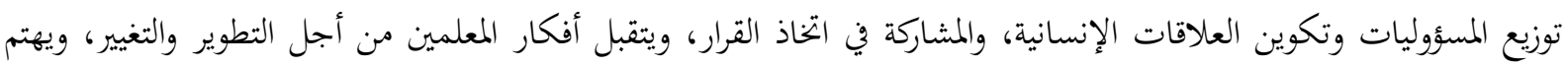

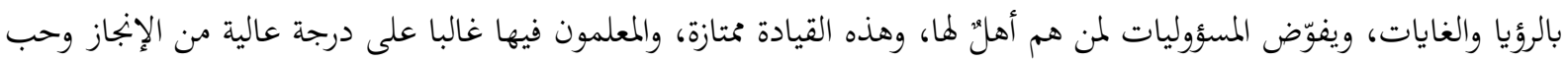

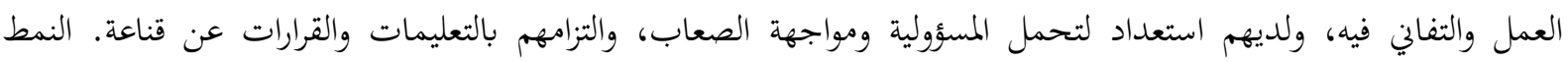

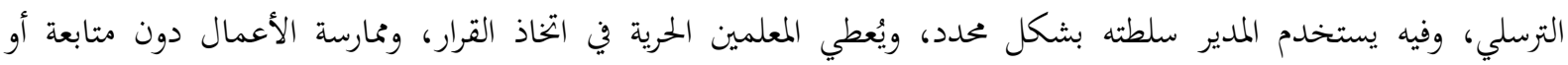

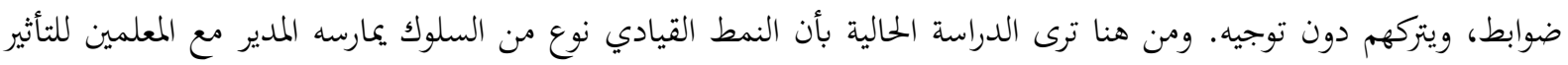

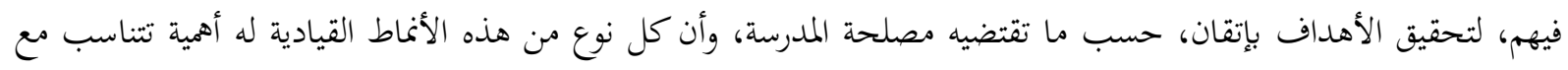

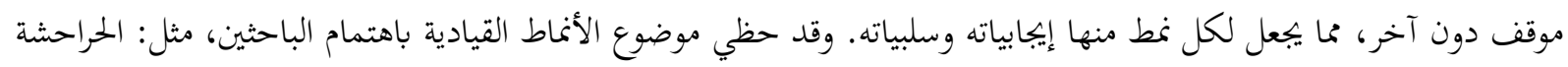
(2008) إذ أشار إلى أن هناك علاقة إيجابية بين النمط القيادي ومستوى الرضا الوظيفي للمعلمين. في حين أوصت دحلائه

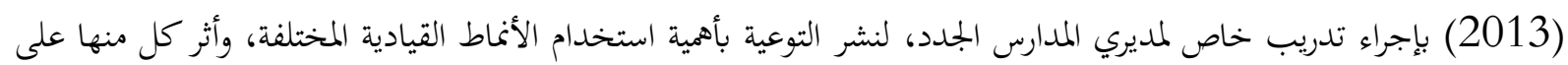

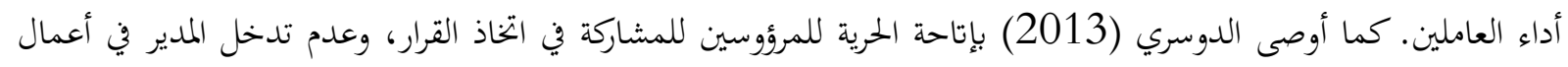

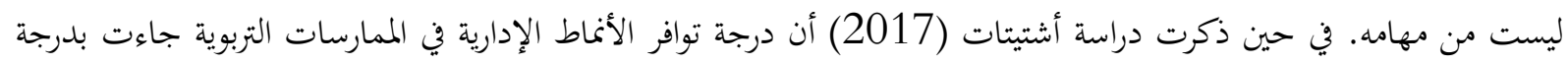

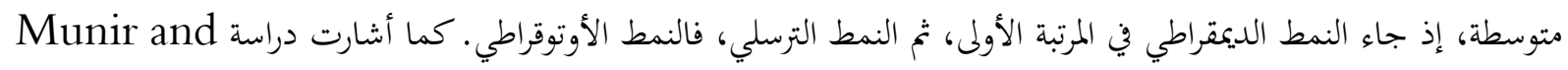
Iqbal الوظيفي للمعلمين، بينما يقلل النمط التسلطي من مستوى الرضا الوظيفي ومستوى الإنتاجية. في حين توصلت دراسة الصبحية (2019) إلى أن النمط القيادي السائد لدى مديري مدارس التعليم الأساسي هو النمط الديموقراطي، وفي المرتبة الثانية

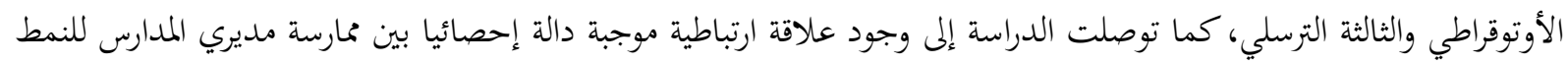

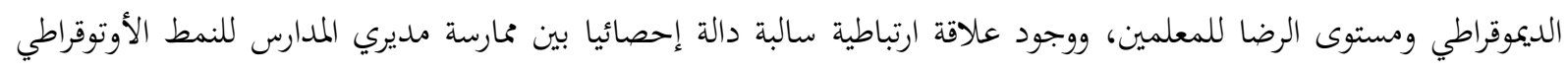

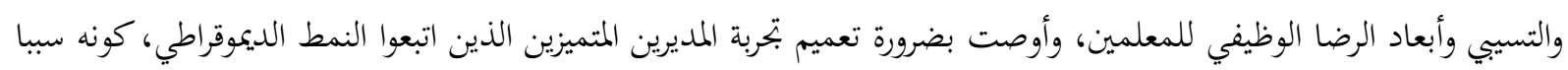
في تحقيق الرضا الوظيفي. وتتنوع أنماط السلوك القيادي من موقف لآخر ومن شخصية لأخرى، ومن أبرز الأنماط القيادية المنتشرة

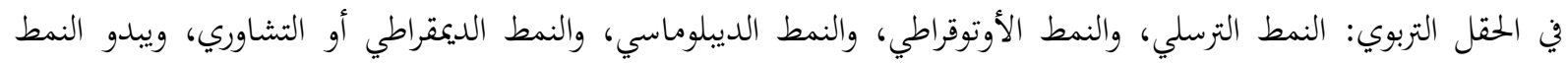

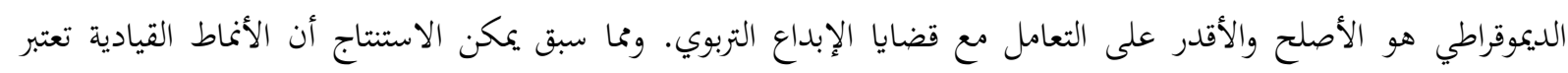

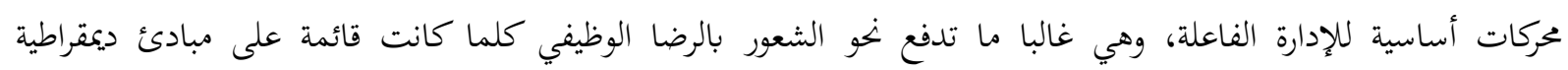

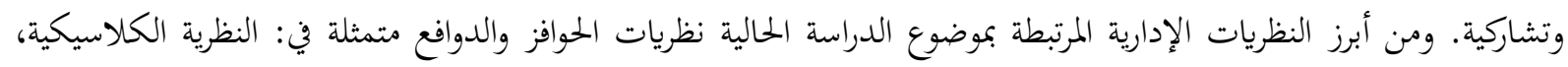
ونظرية YX، ونظرية العلاقات الإنسانية، ونظرية الحاجات الإنسانية. واعتمدت الدراسة الحالية على نظرية هيكلية الحاجات

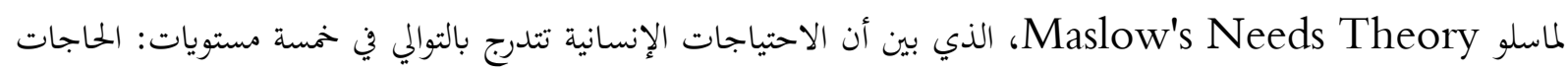

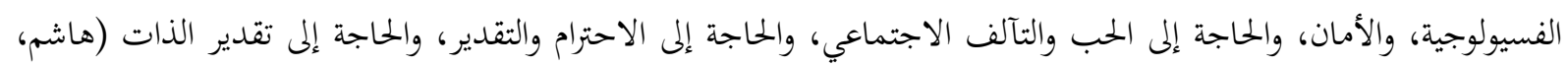

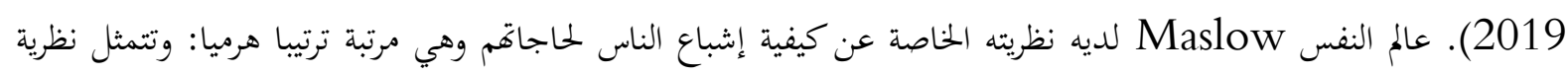

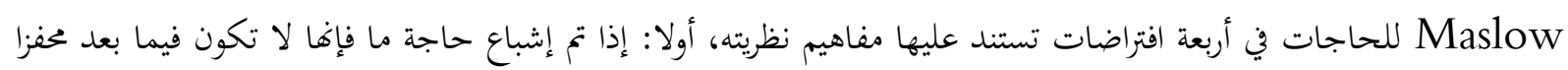

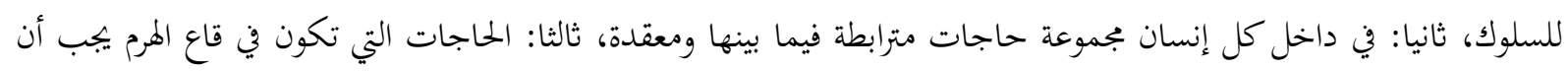

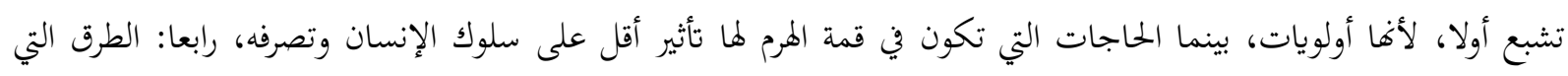

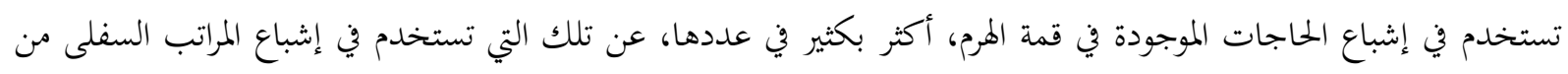
الهرم. حيث تكون حاجات الإنسان هذه متدرجة في خمس حاجات، بداية من الحاجات الفسيولوجية متمثلة في الحاجة إلى 
الأكل والشرب والهواء، تليها الحاجة إلى الأمان متمثلة في حاجة الإنسان للشعور بالأمان المادي والنفسي، تليها حاجة الإنسان

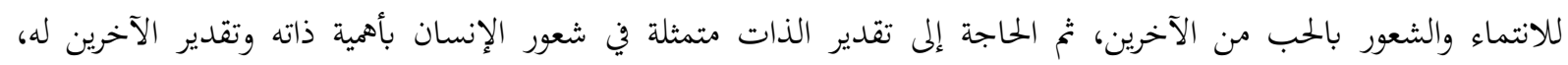

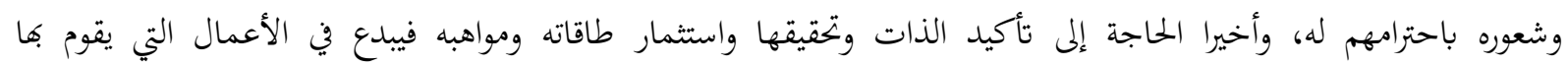

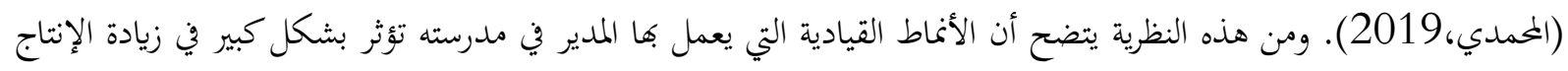
والإبداع وتحقيق الرضا الوظيفي في الجانب الإيجابي أو في الجانب السلبي. فاهتمام المدير بالمعلمين ومراعاة أحوالهم وظروفهم،

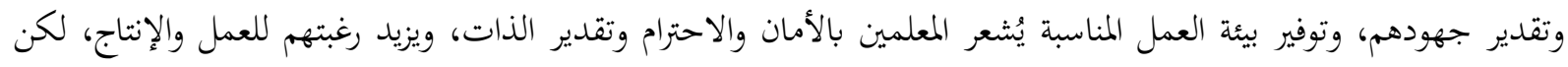

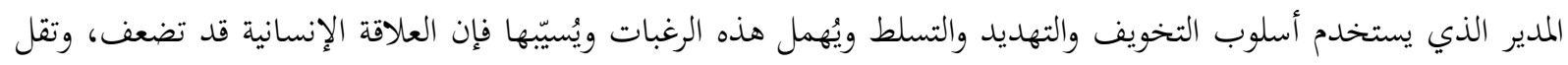

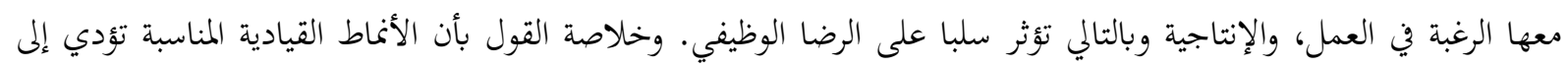
إشباع بعض الحاجات التي يسعى الفرد إلى تحقيقها، ليشعر بالرضا الوظيفي. ترعائ.

مشكلة الدراسة

يحتلّ تطوير أنماط القيادة في المؤسسات التربوية الصدارة في الأنظمة التعليمية، ويصعبُ التقدم في تلك الأنظمة إلا بأخذ

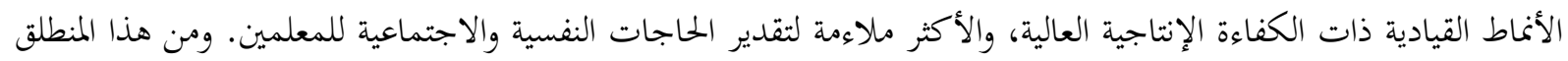

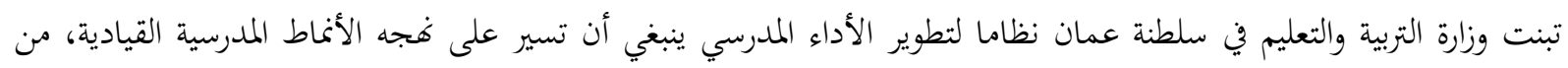

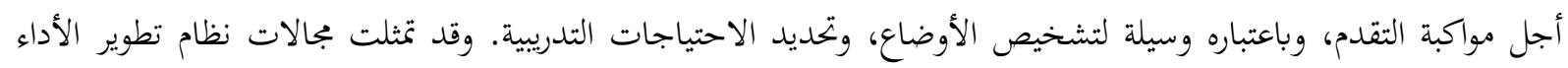

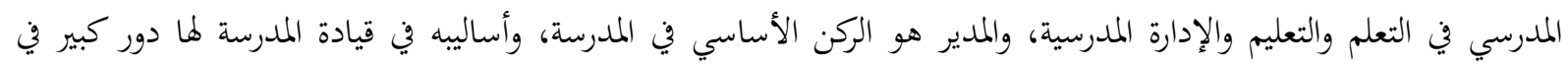
تحقيق الرضا الوظيفي للمعلمين من عدمه، لذلك ينبغي أن تتوافر فيه صفات القيادة الأكثر كفاءة (وزارة التربية والتعليم،

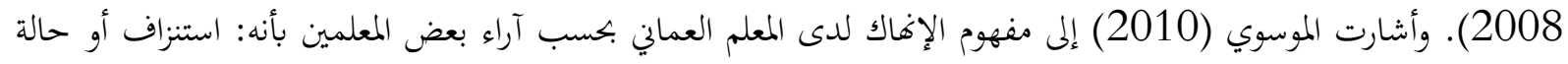

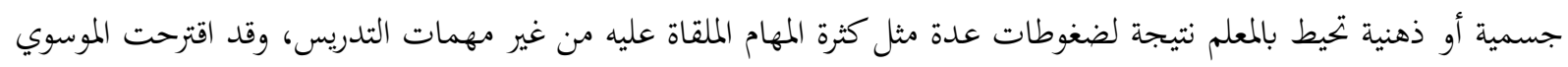

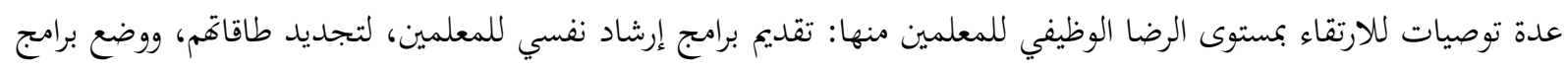

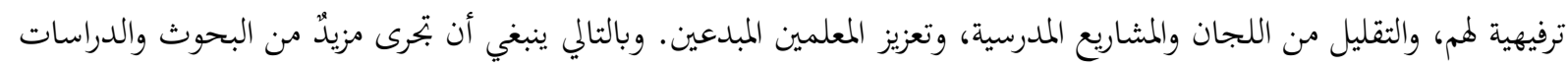

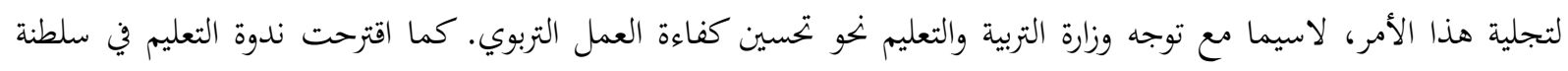

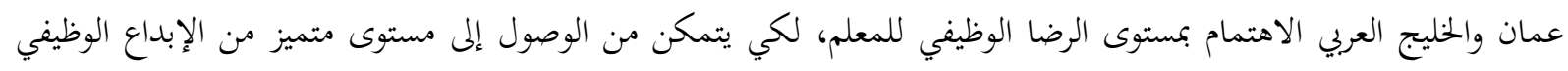

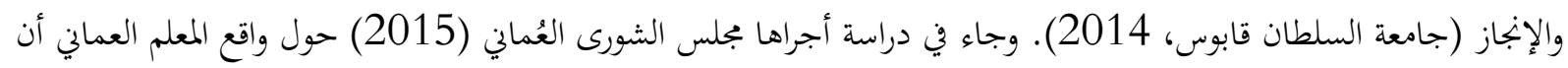

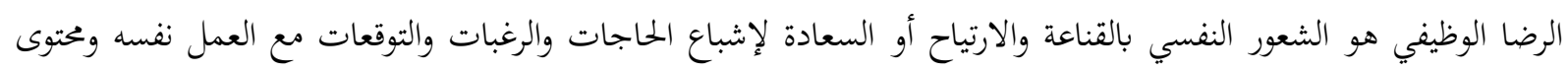

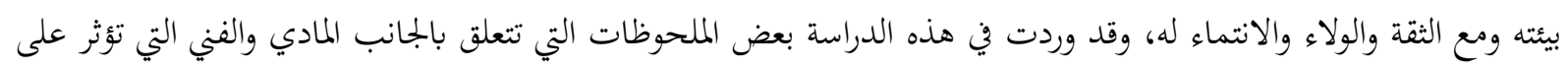

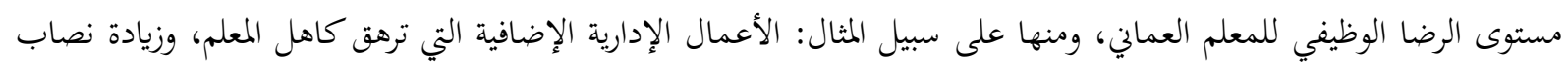

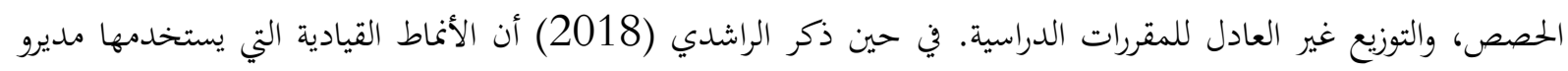

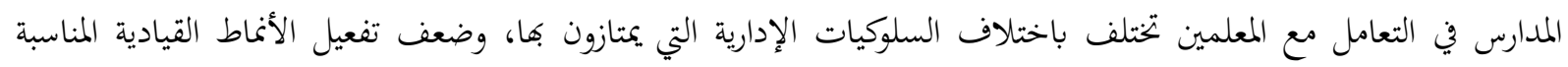
لظروف المعلمين قد يؤدي إلى قلة تققيق الأهداف المنشودة للعملية التعليمية، وكذلك توظيف القيادات الإدارية في الوظائف التي

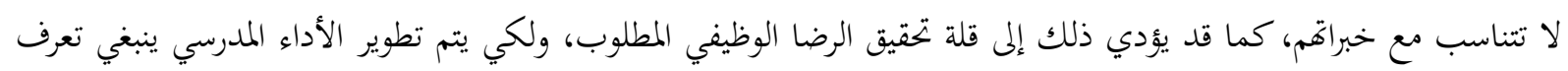

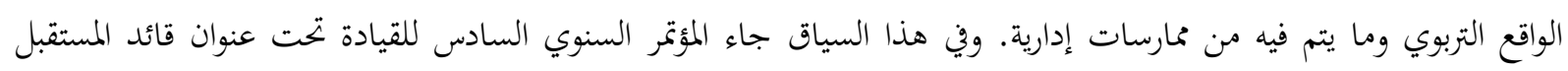
(2018) مستعرضا الصفات التي يجب أن تتوافر في قائد المستقبل، والمتمثلة في إثبات دوره القيادي أمام الآخرين، والرؤيا

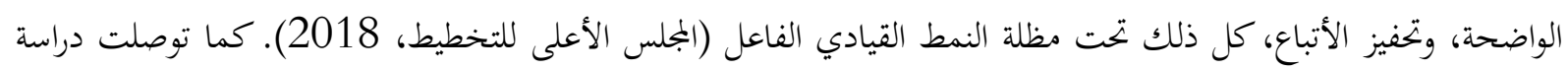


الشيزاوية (2008) إلى وجود علاقة إيجابية بين النمط القيادي الديمقراطي لمديري المدارس ومستويات الرضا الوظيفي السائدة

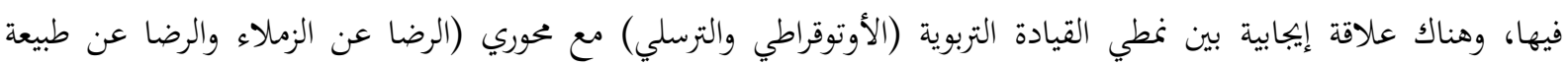

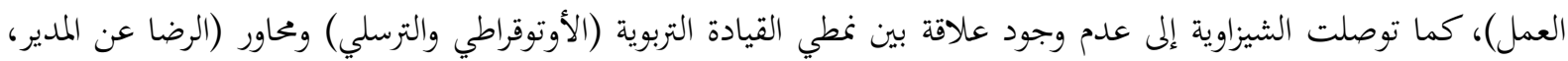

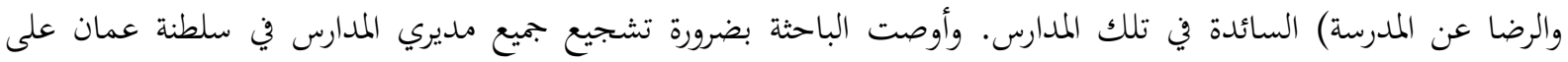
استخدام النمط القيادي الديمقراطي، لأنه يوفر التعاون والمناخ النفسي والاجتماعي للمعلمين، ثم يؤثر إيجابيا على الأداء والإنجاز

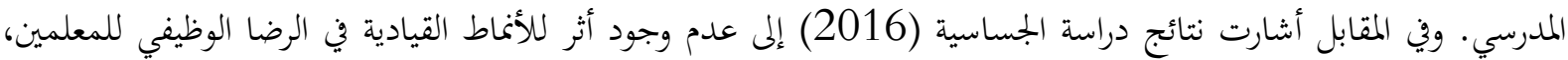
حيث أظهرت المتوسطات نتائج عالية لممارسة الأنماط القيادية مع مستويات متوسطة للرضا الوظيفي، وكان معامل الدلالة أقل من

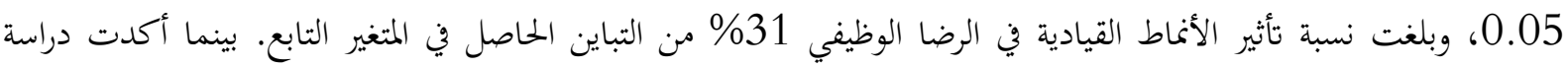

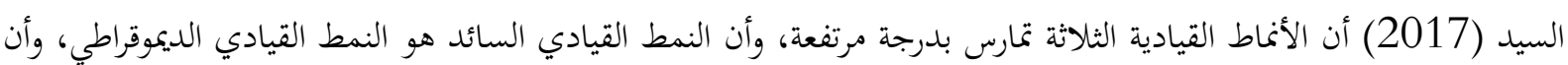
درجة الرضا الوظيفي المعلمين كانت مرتفعة، كما توصلت إلى عدم وجود فروق ذات دلالة إحصائية بين متوسطات درجات ممارسة مديري المدارس للنمط القيادي الأوتوقراطي والحر تعزى لمتغير الحبرة والمؤهل الدراسي. في حين توصلت دوريكي دراسة الراشدي (2018) إلى أن مديري مدارس التعليم الأساسي للصفين (11-12) بمحافظة شنمال الباطنة يستخدمون جميع الأنماط الإدارية

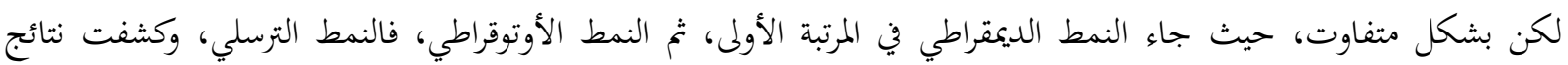

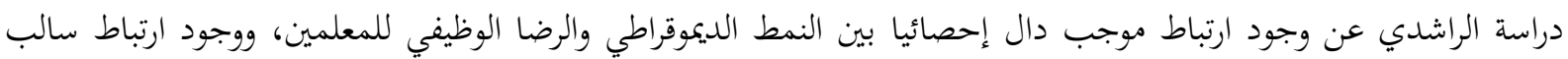
دال إحصائيا للنمطين الأوتوقراطي والترسلي وبين الرضا الوظيفي للمعلمين. وبناء على ما سبق فإن الأنماط المباط القيادية الإدارية تؤثر

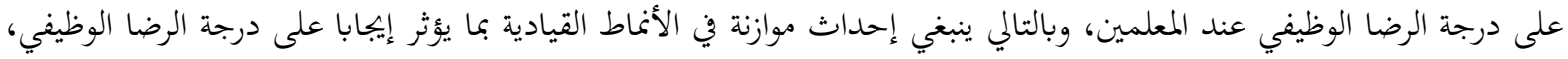
ويدفع هذا الاستنتاج إلى إجراء دراسات أخرى جديدة، لمعرفة درجة التأثير بين المتغيرين. وبالتالي فيمكن أن تتقرر مشكلة الدراسة في دراسة الأماط القيادية لمديرات مدارس الحلقة الأولى بمحافظة شمال الباطنة، وعلاقتها بالرضا الوظيفي لمعلمات المجال الأول.

أسئلة الدراسة 1. ما الأنماط القيادية التي تمارسها مديرات مدارس الحلقة الأولى كما تراها معلمات المجال الأول في محافظة شمال الباطنة التعليمية

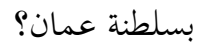

2. ما مستوى الرضا الوظيفي لمعلمات المجال الأول في مدارس الحلقة الأولى بمحافظة شمال الباطنة التعليمية من وجهة نظرهن؟

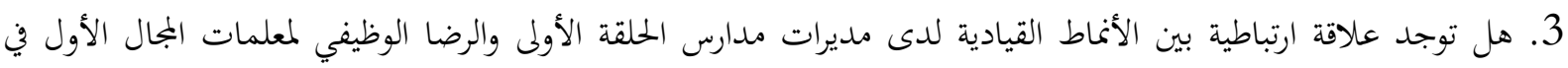

تبدو أهمية هذه الدراسة في كوها تتناول موضوعين مهمين في مجال الإدارة التربوية في سلطنة عمان وهما: الأنماط القيادية، والرضا الوظيفي باعتبارهما مرتبطان بفئة مهمة في المجتمع التربوي، ولمما دور بارز في تحقيق الإنجاز في المدرسة، والمساهمة في صندانع

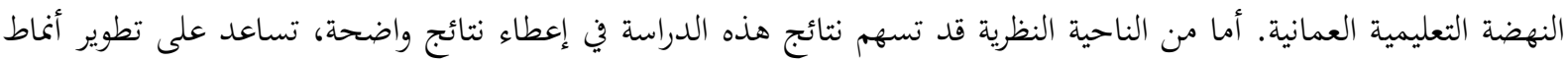
القيادة لدى الإدارة التربوية المدرسية من خلال تركيزها على النمط القيادي الأنسب لدى مديرات مدارس الحلقة الأولى في محافظة

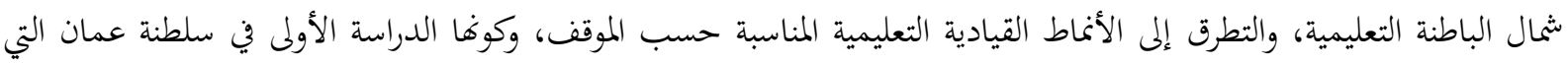
تسلط الضوء على الأنماط القيادية للإناث. أما من الناحية التطبيقية فإنه يتوقع من نتائج هذه الدراسة أن تقدم بيانات للمسؤولين

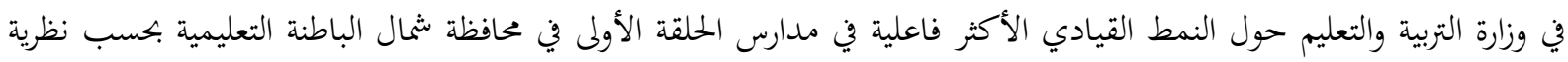


الحاجات Maslow، وبالتالي قد تساعد في وضع الخطط والبرامج التدريبية الأكثر ملاءمة للنهوض بمستوى هذه الممارسات الإدارية.

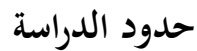

$$
\text { الحدود الزمنية: تم تطبيق هذه الدراسة في الفصل الدراسي الثاني من العام الدراسي 2019 2020. }
$$
الحمدود المكانية: تم تنفيذ الدراسة في مدارس محافظة شمال الباطنة في ولايات: صحار، وشناص، ولوى، وصحم، والخابورة، والسويق، وتم اختيار محافظة شمال الباطنة، كوها أكبر محافظة تعليمية، ويوجد بها طاقات بشرية متنوعة. الحدود البشرية: تم تنفيذ

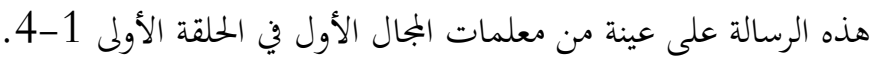
الحدود الموضوعية: الأنماط القيادية السائدة لدى مديرات مدارس التعليم الأساسي في مدارس الحلقة الأولى 1-4، وهي: النمط القيادي الديموقراطي، والنمط القيادي الأوتوقراطي، والنمط القيادي الترسلي، وعلاقتها بالرضا الوظيفي لمعلمات المجال الأول في محافظة شمال الباطنة.

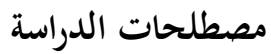
1. وسيتم تعريفه من خلال مناقشة مصطلحي النمط والقيادة كما يأتي: النمط كما عرفه مجمع اللغة العربية (2005،

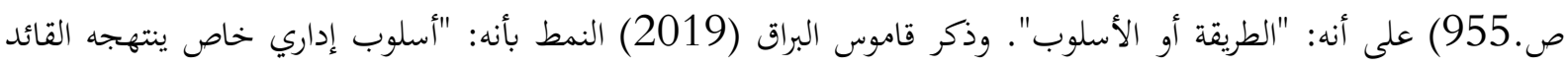

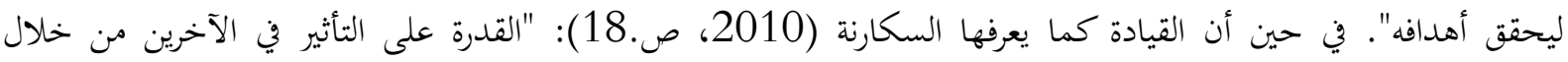

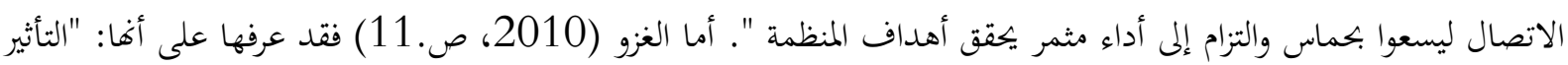
في شخص أو بجموعة أشخاص وتوجيهُم وإرشادهم من أجل كسب تعاوغم وحفزهم على العمل بأعلى درجة من الكفاءة في

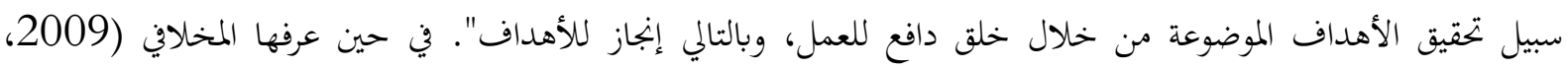

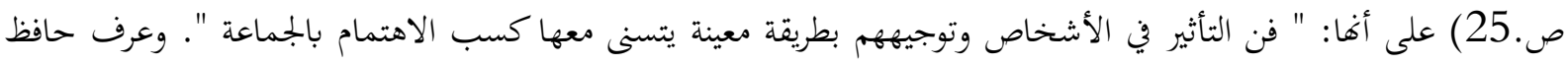

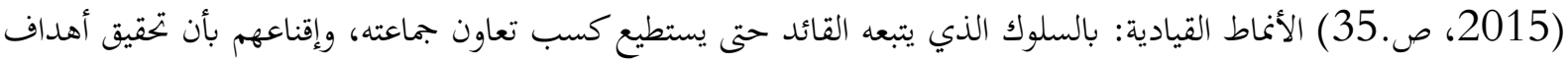
المنظمة تحقيق لأهدافهم". وفي سياق آخر أشار حافظ (2015، ص. (35) بأن الأنماط القيادية: "بجموعة من السمات السلوكية

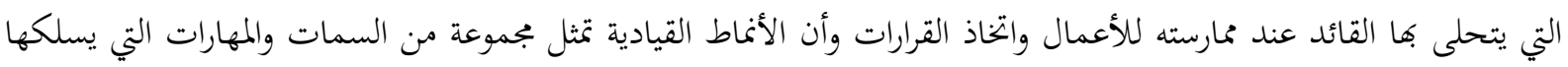

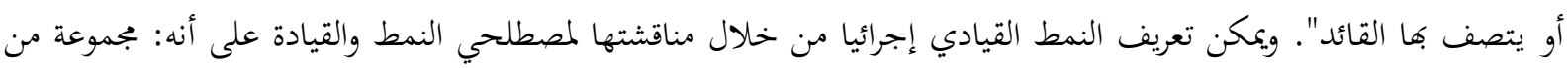

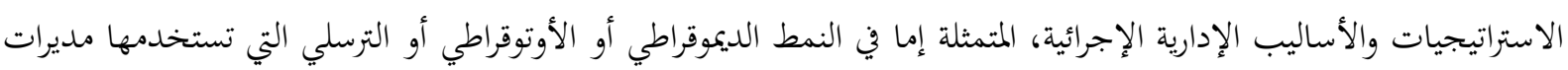

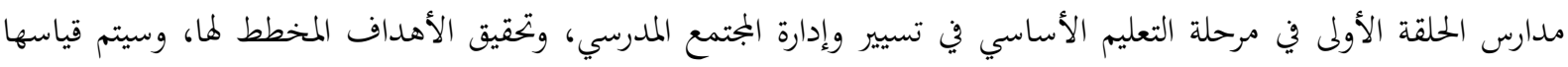
بواسطة الاستبانة المعدة لذلك الغرض.

2. 2 الرضا الوظيفي:

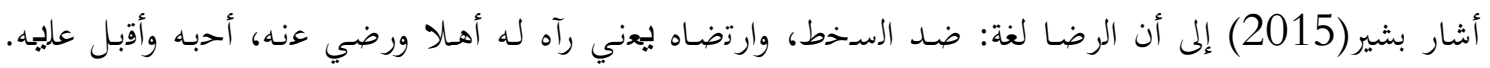

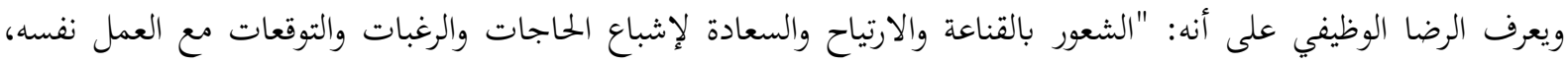

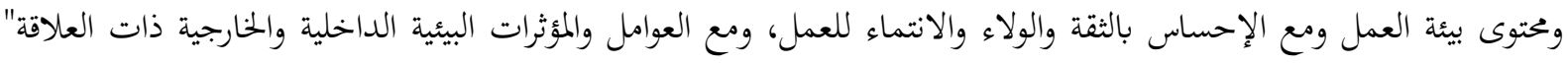
(أبو عساف والمرعي، 2019، ص.153). في حين يعرفه محمد (2018، ص.11) بأنه: "بجموعة العوامل ذات الصلة بالعمل 
الوظيفي، والتي تقاس أساسا بقبول الفرد ذلك العمل بارتياح ورضا نفس وفاعلية بالإنتاج نتيجة للشعور الوجداني الذي يمكن للفرد

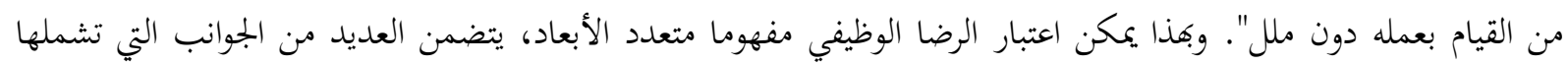

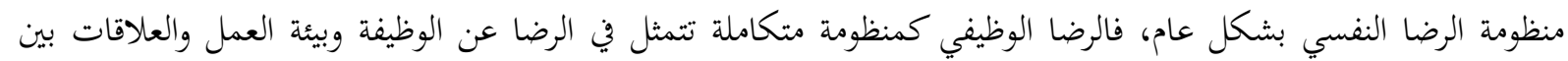

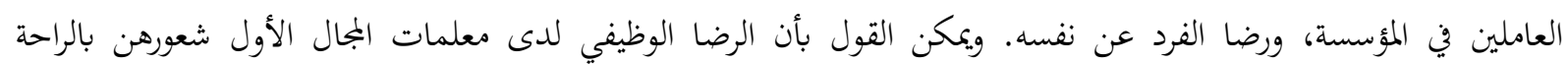

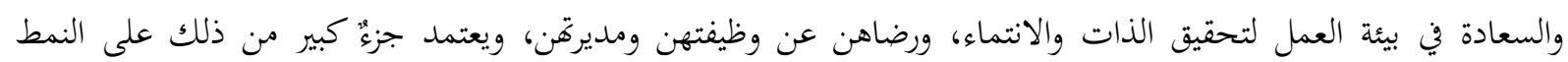

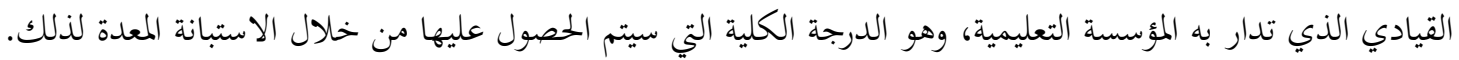

\section{منهجية الدراسة}

وظفت الدراسة الحالية المنهج الوصفي الارتباطي، للتعرف على آراء معلمات المجال الأول حول الأنماط القيادية لمديرات

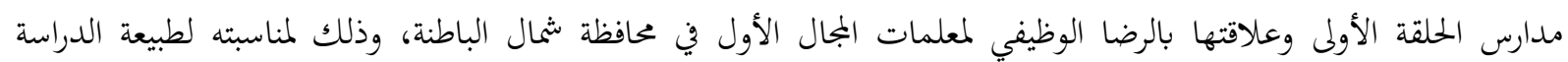
الحالية، وباعتباره يصف الظاهرة كما هي كمَّا وكيفا، فهو يهتم بدراسة العلاقات التي تربط بين أجزاء الظاهرة المدروسة بواسطة

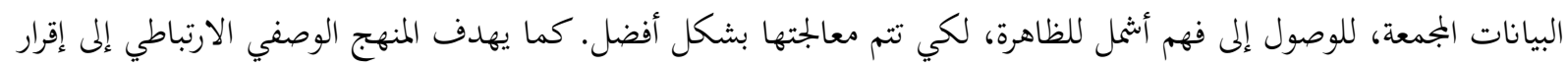

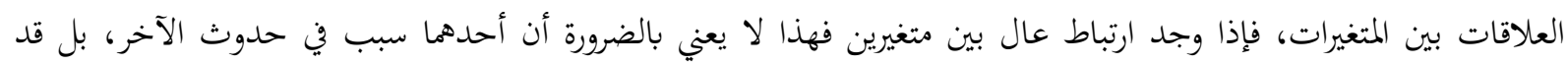

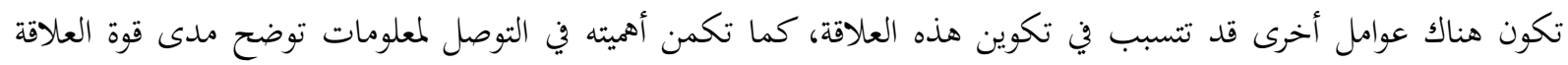

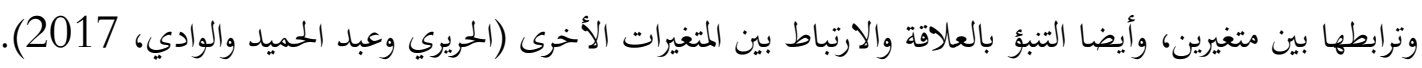

\section{مجتمع الدراسة وعينتها والأدوات}

يشمل بجتمع الدراسة جميع معلمات المجال الأول في مدارس الحلقة الأولى 1-4 من التعليم الأساسي في محافظة شمال الباطنة في ولايات: شناص، ولوى، وصحار، وصحم، والخابورة، والسويق، القائمات على رأس عملهن في العام الدراسي

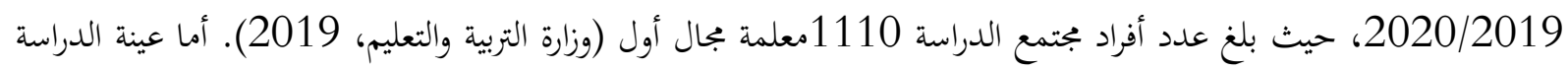

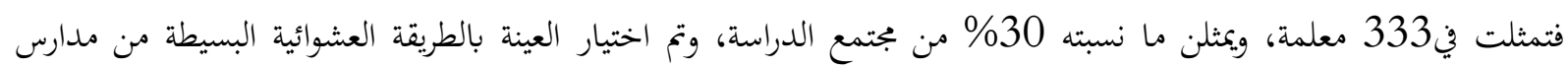
الحلقة الأولى في محافظة شمال الباطنة.

اشتملت الدراسة الحالية على أداتين، تمثل الهدف من الأداة الأولى (استبانة قياس الأنماط القيادية لمديرات مدارس الحلقة

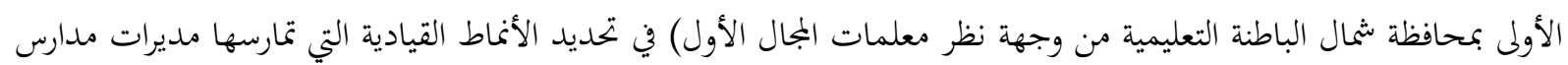

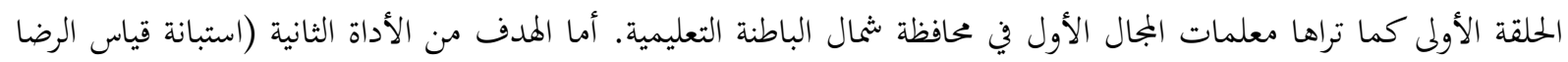

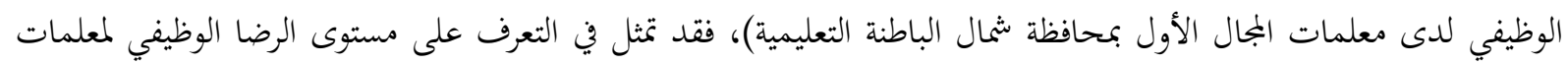

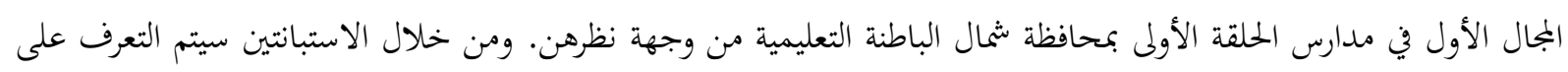

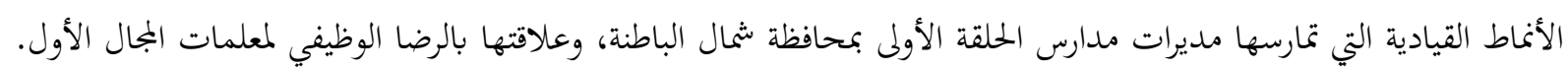

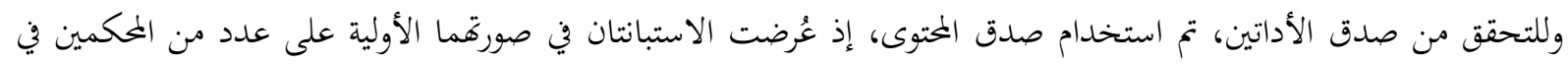

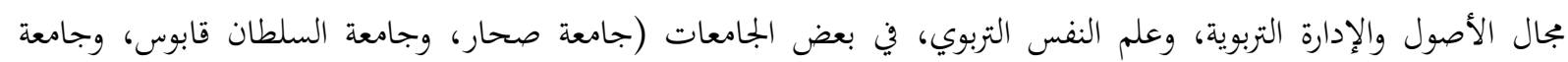
الشرقية)، وبعض المختصين في وزارة التربية والتعليم في تطوير الأداء المدرسي، لتحديد مدى تمثيل الفقرات للسمات المراد قياسها،

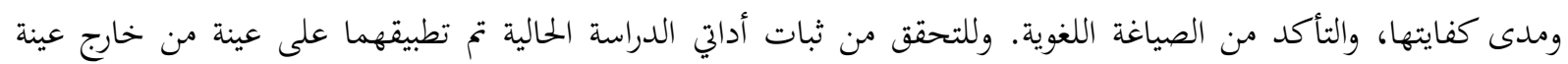

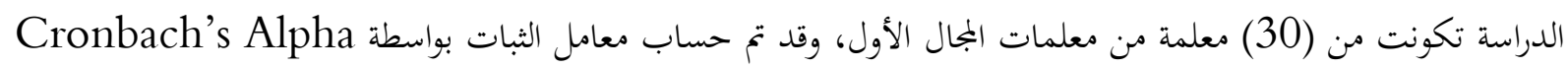


Coefficient، حيث بلغ معامل ثبات الاستبانة الأولى الخناصة بالأنماط القيادية 0.93، أما الاستبانة الثانية الخاصة بالرضا

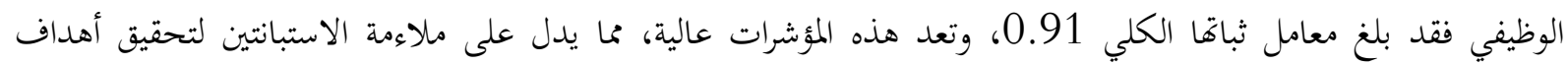
الدراسة الحالية، كما أشار ثابر إلى أن الثبات الكلي للمقياس يكون مناسبا عندما تلكون قيمته (Taber,2016). وبعد الحصول على الموافقة الرسمية من المكتب الفني للدراسات والتطوير في وزارة التربية والتعليم بتطبيق أداتي الدراسة، وبعد الحصول على الموافقة الرسمية من دائرة تنمية الموارد البشرية بالمديرية العامة للتربية والتعليم بمحافظة شمال الباطنة

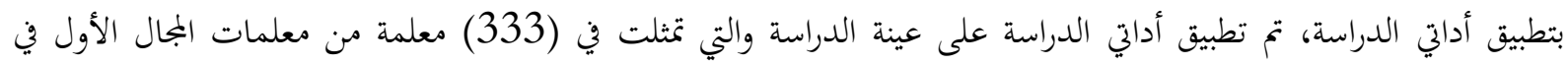
مدارس الحلقة الأولى 1-4 من التعليم الأساسي في محافظة شثمال الباطنة.

\section{الخطوات الإجرائية للدراسة}

الاطلاع على الأدب التربوي المرتبط بموضوع دراسة الأنماط القيادية وعلاقتها بالرضا الوظيفي (أبو عساف والمرعي،

2019، البارودي، 2015، محمد، 2018) والدراسات والبحوث المرتبطة بموضوع دراسة الأنماط القيادية وعلاقتها بالرضا

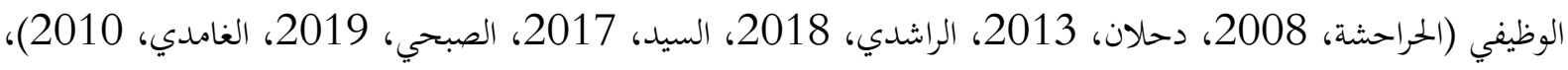

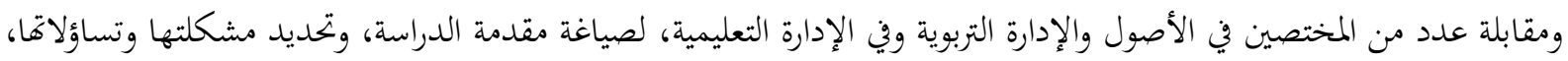

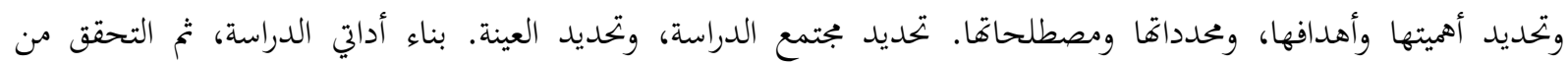
مؤشرات الصدق لمما، حيث تم اعتماد صدق المحتوى. التحقق من ثبات أدات واتي الدراسة باستخدام ألفا كرو نباخ "Cronbach's Alpha Coefficient" الاستبانتين على عينة الدراسة من معلمات المجال الأول. استقبال الردود على الاستبانات عبر الرابط الإلكتروني في برنامج google drive فاستخلاص النتائج والإجابات عن أسئلة الدراسة، وتحليلها ثم مناقشتها.

\section{الأساليب الإحصائية للدراسة}

تمت معالجة البيانات المستخلصة من الاستبانتين، باستخدام معالج البيانات إحصائيا في برنامج SPSS، لإجراء التحليل الإحصائي المطلوب للإجابة عن أسئلة الدراسة، وذلك وفق الآتي: في الإحصاء الوصفي للدراسة وظفت مقاييس النزعة المركزية:

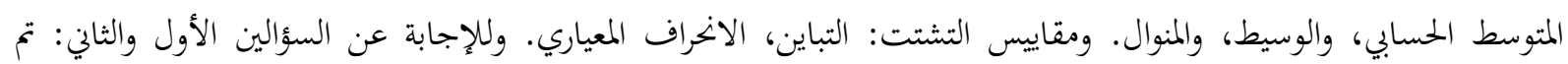

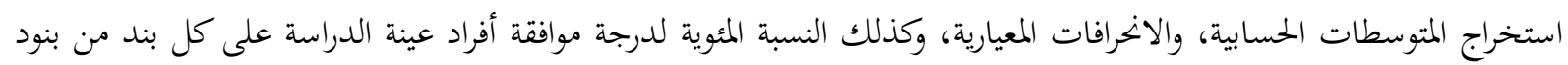

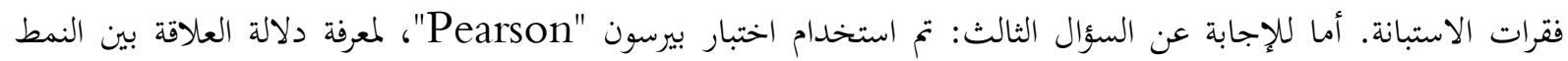
القيادي لمديرات مدارس الحلقة الأولى، والرضا الوظيفي لمعلمات المجال الأول. ولقياس ثبات أداتي الدراسة وظف برسوس معامل ثبات ألفا

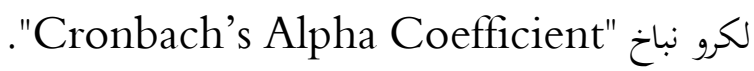

\section{نتائج الدراسة ومناقشتها}

1. ما الأنماط القيادية التي تمارسها مديرات مدارس الحلقة الأولى كما تراها معلمات المجال الأول في محافظة شمال الباطنة بسلطنة

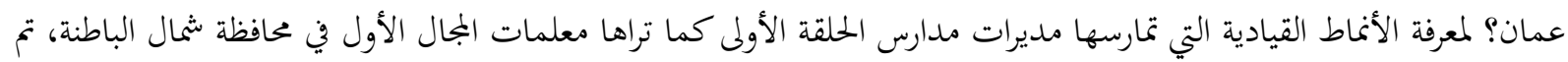
حساب المتوسطات الحسابية والاخرافات المعيارية لتقديرات أفراد العينة لمحاور أداة الدراسة، والجدول 1 التالي يوضح هذه النتائج. 
المتوسطات الحسابية والانحرافات المعيارية للأمناط القيادية التي تمارسها مديرات مدارس الحلقة الأولى كما تراها معلمات

البجال الأول في محافظة شمال الباطنة التعليمية

\begin{tabular}{|c|c|c|c|c|}
\hline درجة الممارسة & الرتبة & اللانحياري & المتوسط الحسابي & محاور أداة الدر اسة \\
\hline عالية جدا & 1 & 0.60 & 4.45 & النمط القيادي الديمقر اطي \\
\hline متوسطة & 2 & 0.91 & 2.93 & النمط القيادي الأوتقر اطي \\
\hline متوسطة & 3 & 1.02 & 2.64 & النمط القيادي الترسلي \\
\hline
\end{tabular}

اتضح من الجدول 1 أن المتوسطات الحسابية للأنماط القيادية التي تمارسها مديرات مدارس الحلقة الأولى كما تراها معلمات المجال الأول في محافظة شثمال الباطنة بسلطنة عمان تراوحت بين 2.64- 4.45، إذ جاء في المرتبة الأولى النمط

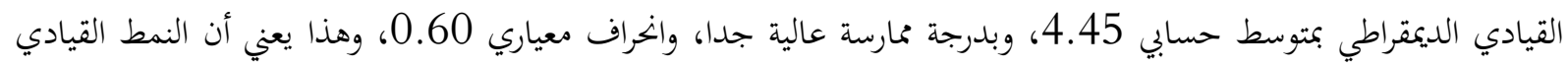

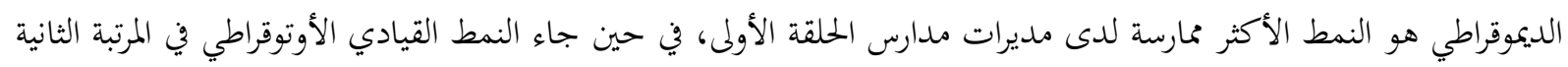

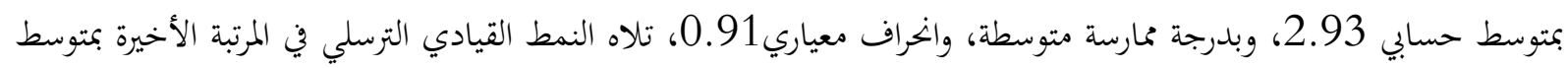
حسابي 64.64، وبدرجة ممارسة متوسطة، وانحراف معياري 1.02. ويمكن تفسير سبب حصول النمط القيادي الديموقراطي على متلى

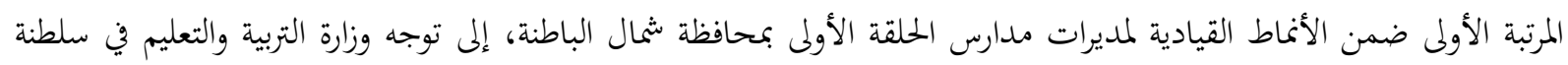

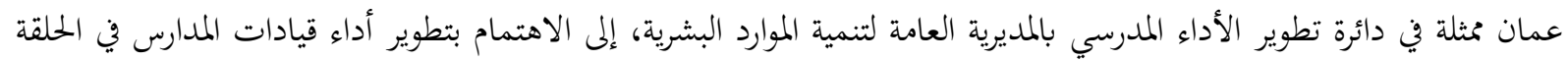

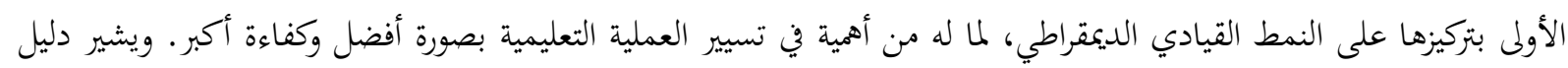
نظام تطوير الأداء المدرسي إلى أن على القيادات المدرسية التحلي بعلد من الميزيات القياديادية التي ينبغي أن تترسخ في في منارسات

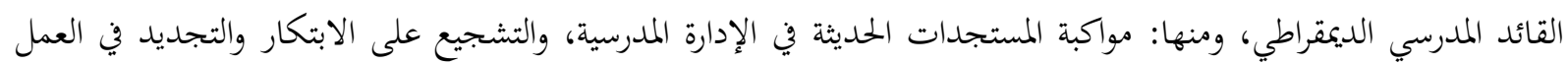

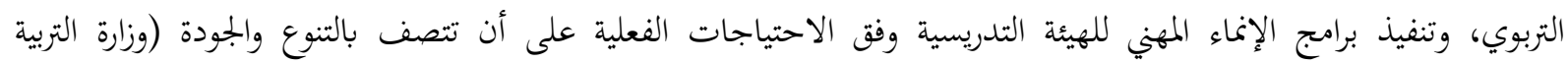
والتعليم.2008). ولذلك فإن تطوير أداء القيادات المدرسية، ورفع كفاءقا الإدارية عن طريق الجودة في خدمات التهات التدريب، والإنماء المهني قد انعكس إيجابا على الأداء الإداري لمديرات مدارس الحلقة الأولى بمحافظة شثمال الباطنة، كما تسعى وزارة التماء التربية والتعليم

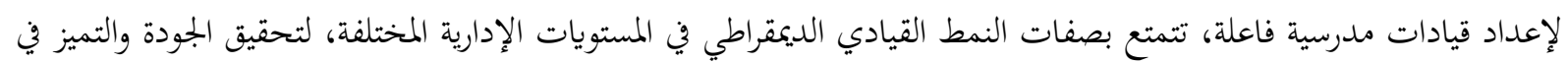
الأداء الوظيفي، وتمكينهم من القيام بوظائفهم بفاعلية وكفاءة، والتطبيق العملي للمهارات الإدارية، وتعريفهم بالمعارف والمافياهيم

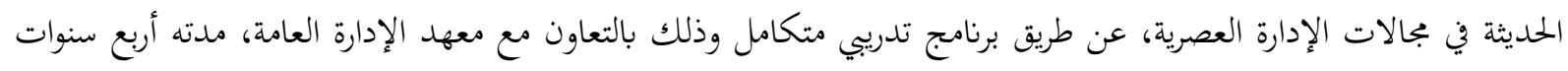
من (2017-2020) بواقع (100) ساعة، مقسمة إلى أربعة أسابيع على مدار العام (التربية والتعليم تواصل جهودها لردا الرامية

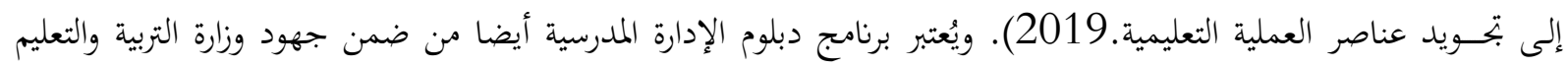

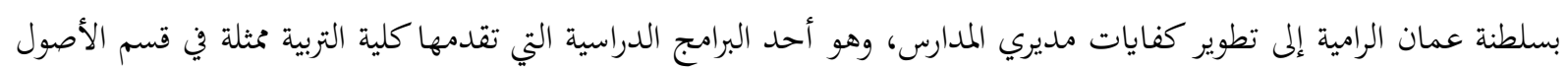

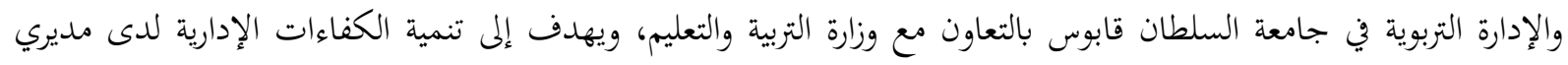


المدارس ومساعديهم، وغرس الاتحاهات الإيجابية المرتبطة بالممارسات القيادية الفاعلة في الججتمع التربوي (وزارة التربية والتعليم.2020). كما ترى الدراسة أن من أسباب حصول النمط القيادي الديموقراطي على المرتبة الأولى بين الأنماط القيادية

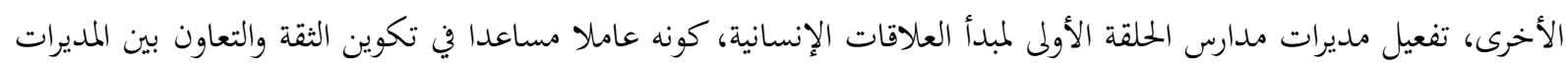
والمعلمات، وهذه واحدة من خصائص العمل الإداري في مدارس سلطنة عمان، تقتضي إشراك المعلمات في وضع خطط مدات مدات للمدرسة، والعمل كفريق واحد مع المديرات. في حين يُعزى حصول النمط القيادي الأوتوقراطي على المرتبة الثانية، بمتوسط حسابي المعاني

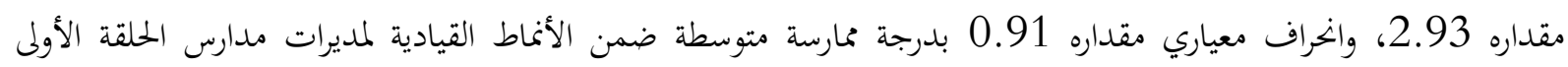

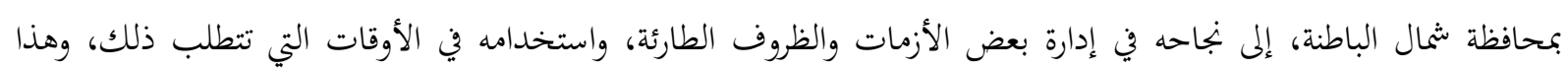

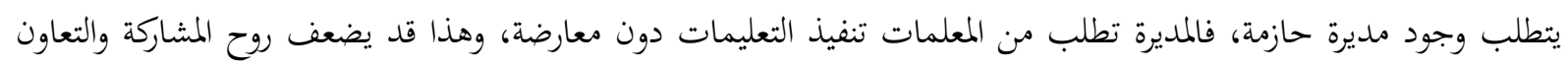

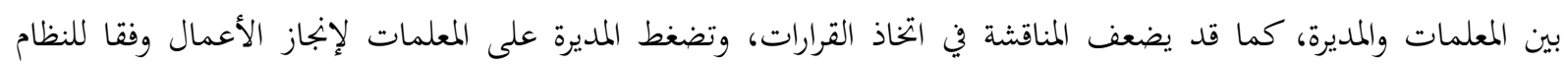

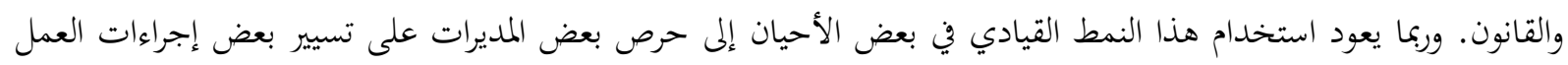

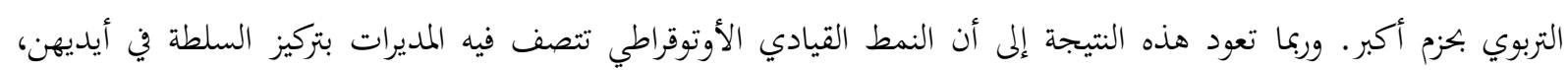

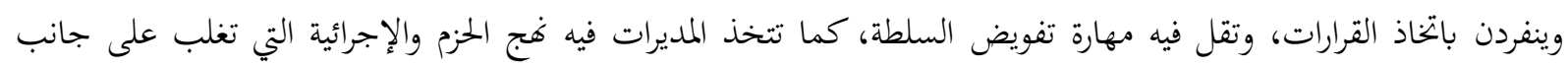

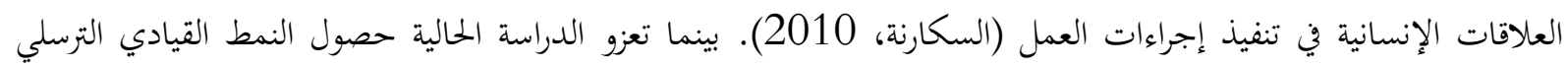

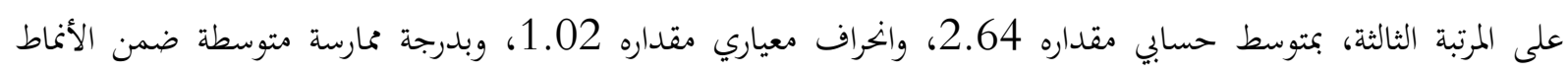

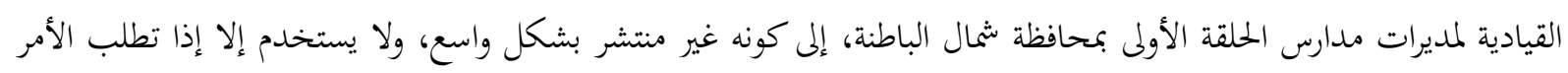

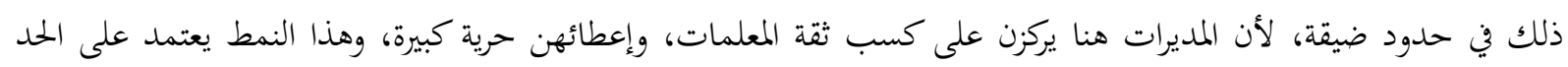

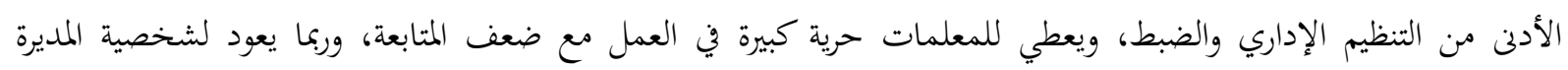
نفسها، فيغلب عليها أسلوب التساهل في جوانب العمل. وفي هذا الإطار تؤكد الدراسة الحالية حصول النمط القيادي الترسلي

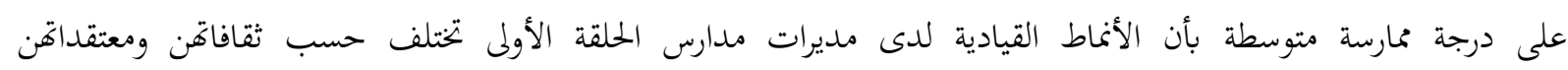

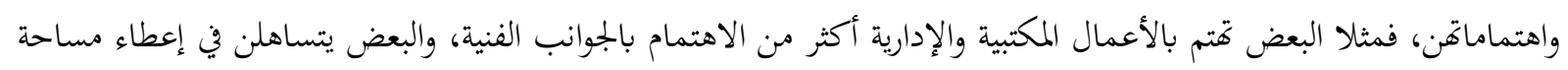

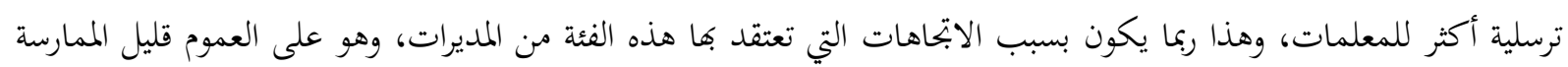

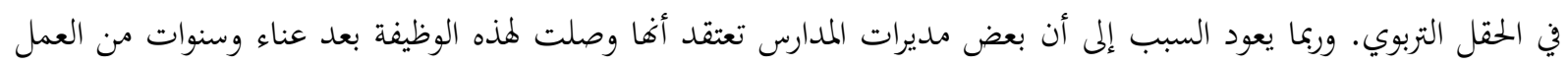

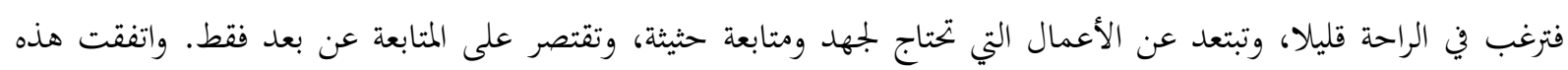

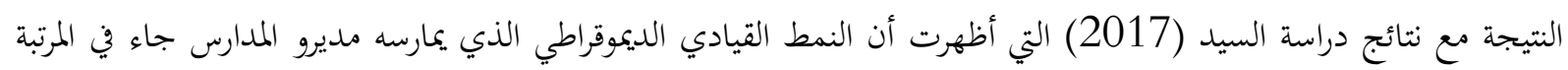

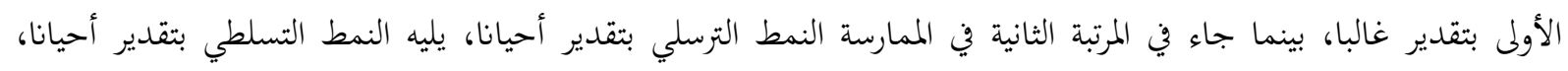

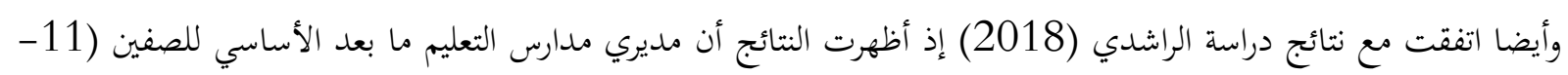

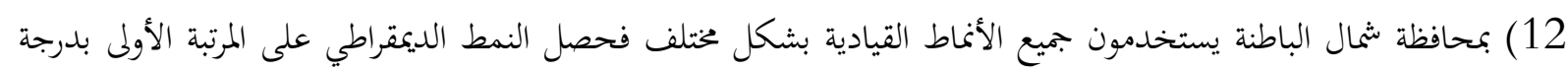

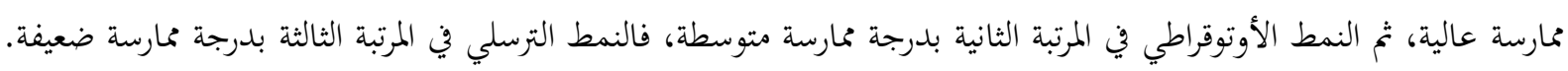

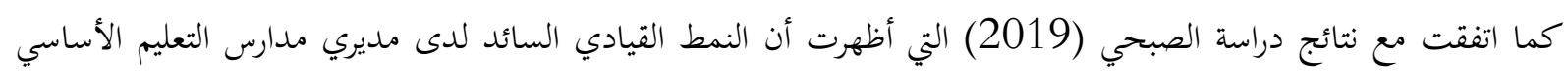

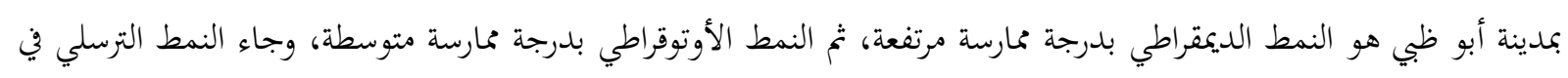

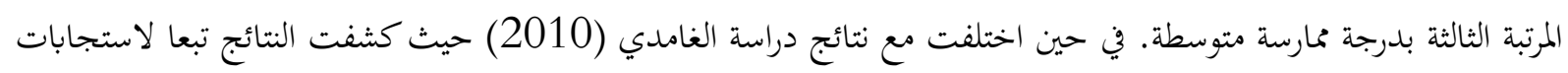
المعلمين لدرجة ممارسة مديري المدارس للأنماط القيادية في المدينة المنورة أن النمط القيادي الديمقراطي جاء داء في الرتبة الأولى بتقدير

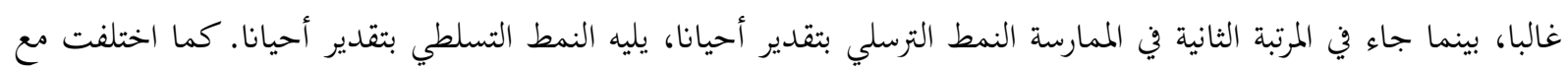
دراسة أشتيتات (2017) فجاء النمط الديمقراطي في المرتبة الأولى وبدرجة ممارسة مرتفعة، ثم النمط الترسلي في المرتبة الثانية 
بدرجة ممارسة متوسطة، وجاء في المرتبة الثالثة النمط الديكتاتوري بدرجة ممارسة متوسطة، وجاء في المرتبة الأخيرة النمط الأوتوقراطي بدرجة ممارسة متوسطة أيضا. وللوقوف على آراء عينة الدراسة حول درجة ممارسة كل نمط من هذه الأنماط تم حساب المتوسطات الحسابية والانحرافات المعيارية لجميع فقرات الاستبانة وفيما يلي عرض لهذه النتائج:

أ- النمط القيادي الديموقراطي

جدول 2 المتوسطات الحسابية والانحرافات المعيارية للنمط القيادي الديمقراطي

\begin{tabular}{|c|c|c|c|c|}
\hline المارسة & الانحر افياري & المتوسط الحسابي & 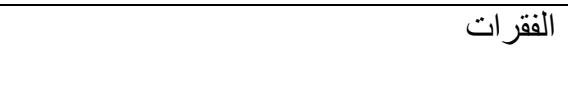 & 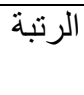 \\
\hline عالية جدا & 0.68 & 4.63 & للرعلمات مديرة المدرسة الجو انب الإنسانية & 1 \\
\hline عالية جدا & 0.72 & 4.62 & في تحسز مديرة المدرسة المعلمات على الاستمرار & 2 \\
\hline عالية جدا & 0.71 & 4.59 & المستجدات مديرة المدرسة اجتماعات، لمناقتة & 3 \\
\hline عالية جدا & 0.68 & 4.54 & تقيّم مديرة المدرسة أداء المعلمات بشكل دقيق. & 4 \\
\hline عالية جدا & 0.79 & 4.51 & تلدعم مديرة المدرسة المشاركة الإيجابية بين & 5 \\
\hline عالية جدا & 0.77 & 4.46 & تلإبداع مديرة المدرسة بتطوير بيئة محفزة & 6 \\
\hline عالية جدا & 0.84 & 4.39 & تلتيح مديرة المدرسة حرية التعبير عن الرأي & 7 \\
\hline عالية جدا & 0.85 & 4.32 & للفعّض مديرة المدرسة بعض المدرسة الصلاحيات & 8 \\
\hline عالية جدا & 0.88 & 4.28 & تشارك مديرة المدرسة المعلمات في آلية صنع & 9 \\
\hline عالية & 0.98 & 4.17 & تتقبل مديرة المدرسة النقد بصورة موضو عية & 10 \\
\hline عالية جدا & 0.60 & 4.45 & النمط القيادي الديمقراطي العام & \\
\hline
\end{tabular}

بيّن الجدول 2 أن المتوسطات الحسابية لفقرات النمط القيادي الديمقراطي تراوحت بين 4.17 - 4.63، وقد بلغ

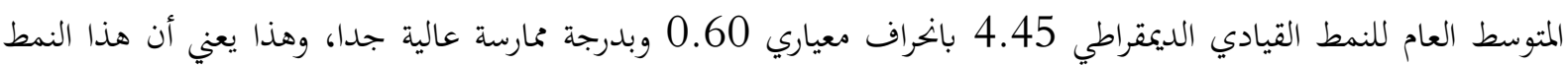
القيادي يسود بدرجة عالية جدا لدى مديرات مدارس الحلقة الأولى في محافظة شمال الباطنة من وجهة نظر معلمات المجال الأول. وقد حصلت الفقرة التي نصها: "تراعي مديرة المدرسة الجوانب الإنسانية للمعلمات" على الرتبة الأولى بمتوسط حسابي وانخراف معياري6806، وبدرجة ممارسة عالية جدا، في المقابل كانت الفقرة التي نصها: "تتقبل مديرة المدرسة النقد بصورة

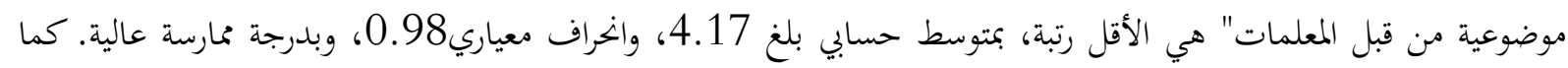

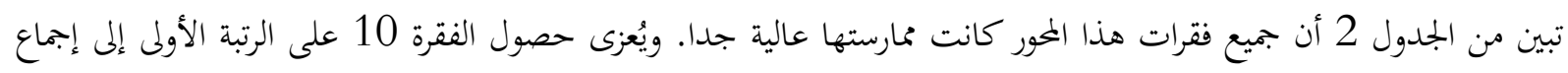

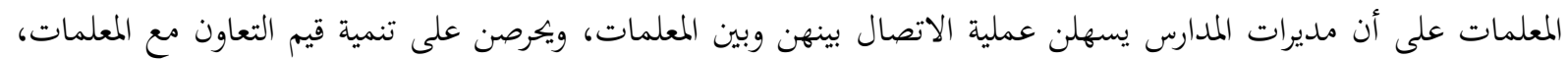
ويشجعن على المشاركة الفعالة، ويؤكدن على تقوية العلاقات الاجتماعية، ومراعاة الجوانب الإنسانية للمعلمات متمثلة في الاحترام والتقدير، ومراعاة الفروق الفردية بين المعلمات، فهذا كله يسهم في تقوية العلاقات الإنسانية بين مديرة المدرسة ومعلماتها، وهذا بدوره ينعكس إيجابيا على تحقيق الأهداف التربوية. وفي هذا الإطار يؤكد يامنة وخير الدين (2019) على ألى أن المديرة الديمقراطية

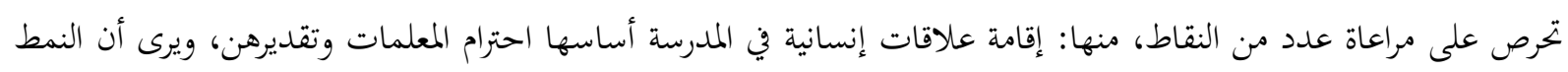


الديمقراطي له دور كبيرٌ في بناء العلاقات الإنسانية بين المديرة والمعلمات، مما ينجم عنه مجتمع مدرسي متماسك وقوي. ولعل

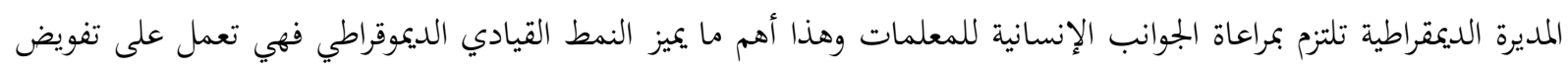
السلطات، ومشاركة المعلمات في اتخاذ القرار، والاهتمام بالعلاقات الإنسانية، ممثلة في المعاملة الحسنة، والثقة المتبادلة، والاهتمام

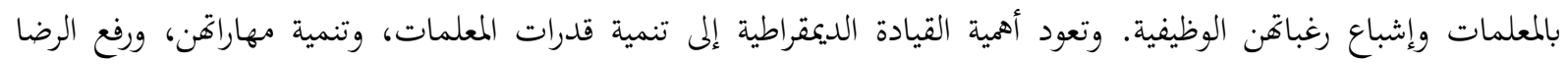

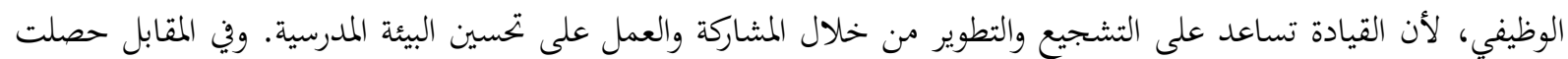

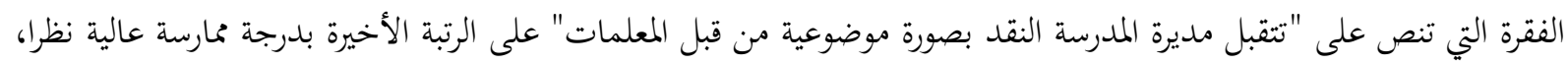

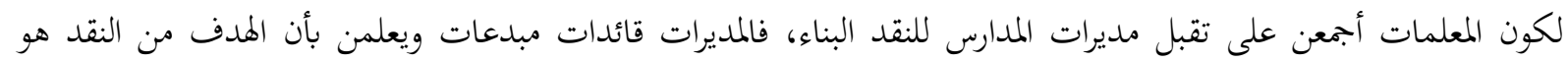

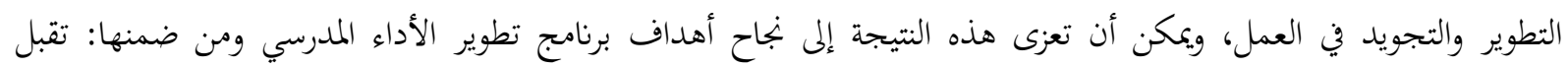

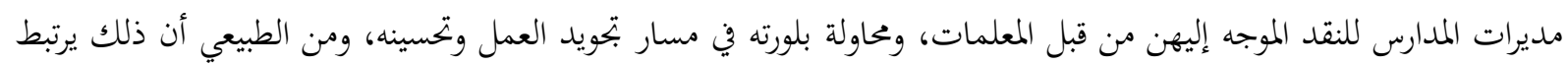

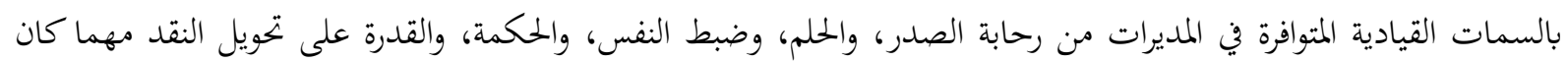
نوعه لصالح مسار العمل التربوي.

ب- النمط القيادي الأوتوقراطي

جدول 3 المتوسطات الحسابية والانحرافات المعيارية للنمط القيادي الأوتوقراطي

\begin{tabular}{|c|c|c|c|c|}
\hline 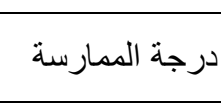 & المعياري اف & الحستيط & 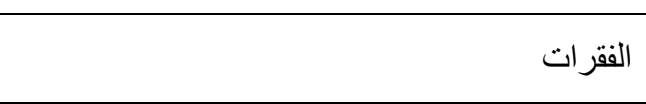 & 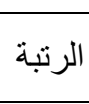 \\
\hline عالية & 0.98 & 4.11 & تحعل. العب مديرة المدرسة المعلمات على تقصير هن في & 1 \\
\hline عالية & 1.14 & 3.98 & تحترصة العمل. & 2 \\
\hline متوسطة & 1.36 & 3.17 & الطعبق مديرة المدرسة القو انين و التعليمات على & 3 \\
\hline متوسطة & 1.28 & 2.78 & تؤدي مديرة المدرسة كافة المهام دون تفويض. & 4 \\
\hline متوسطة & 1.30 & 2.72 & تصعدر مديرة المدرسة القرارات دون إنر الك & 5 \\
\hline متوسطة & 1.36 & 2.71 & التحتيلي مديرة اللطدرسة على المؤليات دون النظر إلى بقية المستية & 6 \\
\hline ضعيفة & 1.29 & 2.57 & تستخدم مديرة المدرسة أسلوب النقد عند مناقشة & 7 \\
\hline ضعيفة & 1.32 & 2.52 & التجل بين المعلمات. & 8 \\
\hline ضعيفة & 1.31 & 2.49 & توجه مديرة المدرسة المعلمات بطريقة تسلطية. & 9 \\
\hline ضعيفة & 1.24 & 2.27 & تعلى الابتكار و الإبداع. & 10 \\
\hline متوسطة & 0.91 & 2.93 & النمط القيادي الأوتوقراطي العام & \\
\hline
\end{tabular}

أبان الجدول 3 أن المتوسطات الحسابية لفقرات النمط القيادي الأوتوقراطي تراوحت بين 2.27 - 4.11، 4.

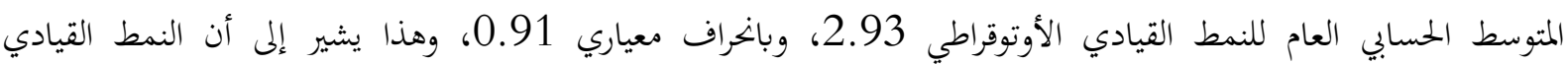

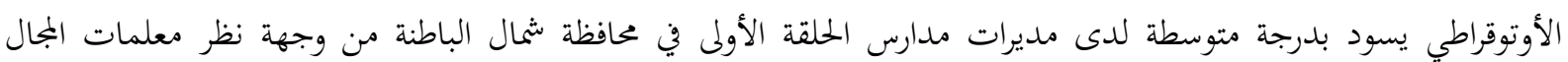

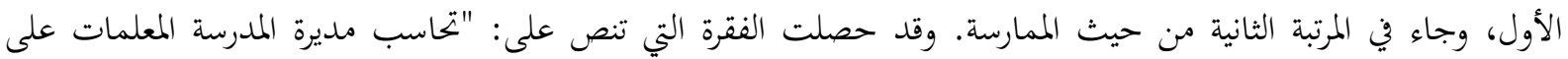

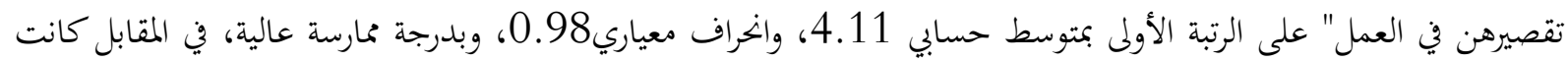

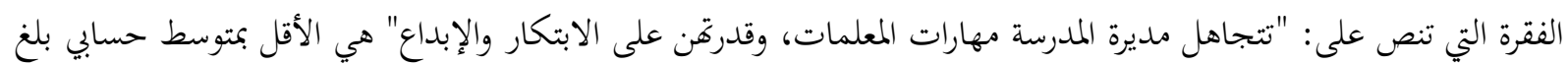

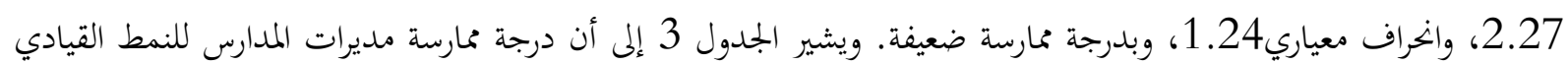


الأوتوقراطي تفاوتت بين الضعيف والمتوسط والعالي، ولعل ذلك يعود إلى حرص مديرة المدرسة على تعميم جميع التعليمات

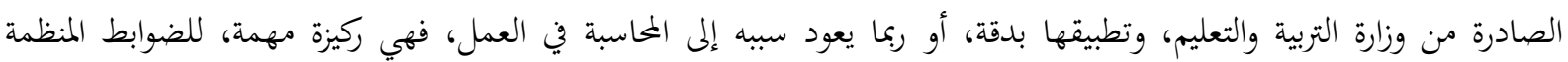

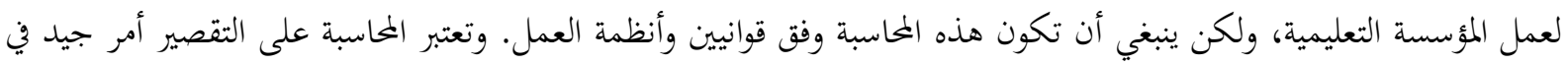

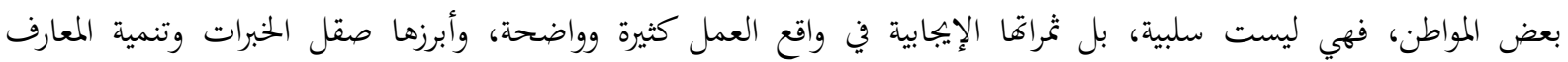

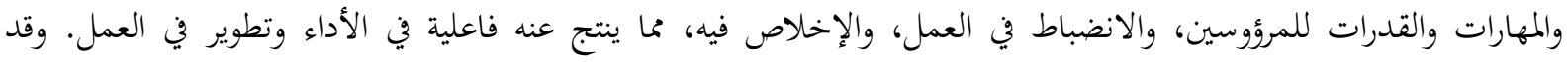

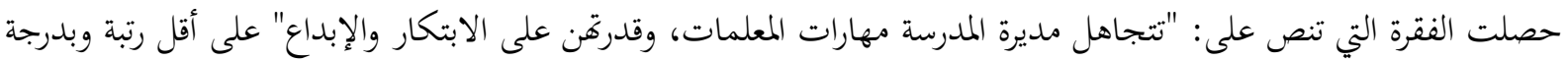
ممارسة ضعيفة، ولعل هذه النتيجة ترجع إلى شخصية المديرة الأوتوقراطية فهي تعتقد بأن تجاهل المعلمات هي أفضل طريقل تريقة

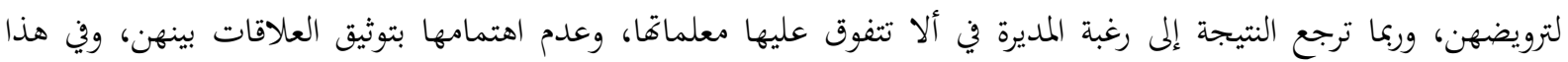

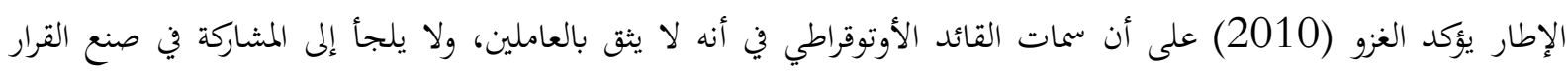

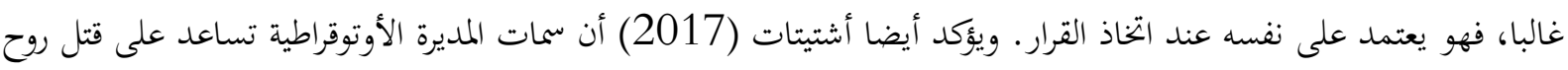
البحث والتفكير والتجديد والابتكار بين العاملين في المدرسة، وهذا يؤدي إلى ضحالة العلاقات الإنسانية في المدرسة، والتأخر في تحسين تأدية العمل، وبطيء النمو والتطوير الذاتي للمعلمات. ت- النمط القيادي الترسلي

جدول 4 المتوسطات الحسابية والانحرافات المعيارية للنمط القيادي الترسلي

\begin{tabular}{|c|c|c|c|c|}
\hline درجة الممارسة & الانحر اف المعياري & المتوسط الحسابي & الفقر ات & الرتبة \\
\hline عالية & 1.24 & 3.50 & 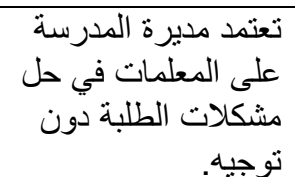 & 1 \\
\hline متوسطة & 1.44 & 3.04 & الاجنى العلاقاتية على المدرسة حسابة & 2 \\
\hline متوسطة & 1.32 & 2.69 & اجتماعدات غيرة مخططة & 3 \\
\hline متوسطة & 1.40 & 2.65 & 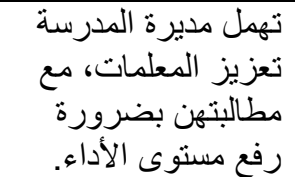 & 4 \\
\hline ضعيفة ا & 1.32 & 2.54 & 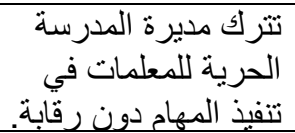 & 5 \\
\hline 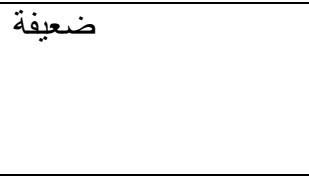 & 1.28 & 2.48 & 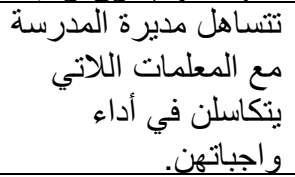 & 6 \\
\hline 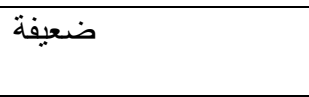 & 1.30 & 2.42 & تسند مديرة المدرسة & 7 \\
\hline 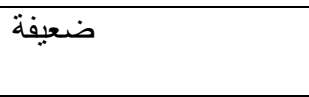 & 1.22 & 2.42 & تقد المعلمات مديرة الدائها. & 8 \\
\hline ضعيفة ا & 1.26 & 2.34 & فتي اتخاذ القرارات المدرسة & 9 \\
\hline 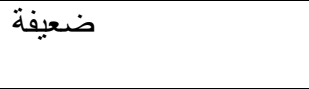 & 1.25 & 2.31 & فتي قبول مديرة المدرسة & 10 \\
\hline
\end{tabular}




\begin{tabular}{|c|c|c|c|}
\hline متوسطة & 1.02 & 2.64 & النمط القيادي الترسلي \\
\hline
\end{tabular}

اتضح من الجدول 4 المتوسط الحسابي العام والانخراف المعياري العام لفقرات محور النمط القيادي الترسلي، إذ تراوحت

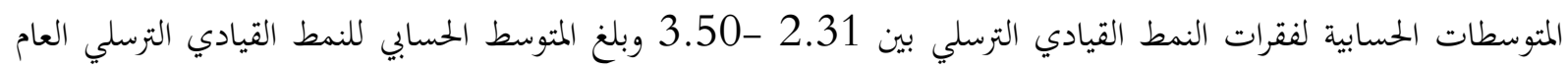
2.64 والاخراف المعياري 1.02، وهذا يدل على أن هذا النمط سائد بدرجة متوسطة ولكنه بدرجة أقل من المستويين

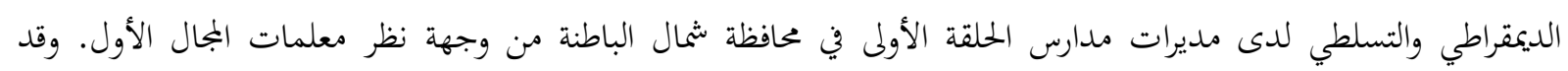
حصلت الفقرة التي تنص على: "تعتمد مديرة المدرسة على المعلمات في حل مشكلات الطلبة دون توجيه" على الرتبة الأولى، بمتوسط حسابي 3.50 وبانحراف معياري24.24، وبدرجة ممارسة عالية، وجاءت في الرتبة الأخيرة الفقرة التي تنص على: لتعلى "تتردد

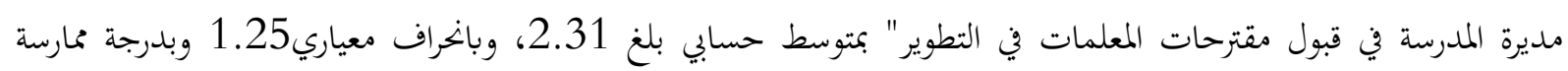
ضعيفة. كما يشير الجدول 4 إلى وجود 6 فقرات من أصل 10فقرات في هذا المحور حصلت على تقدير ضعيف، وربما يعود ذلك

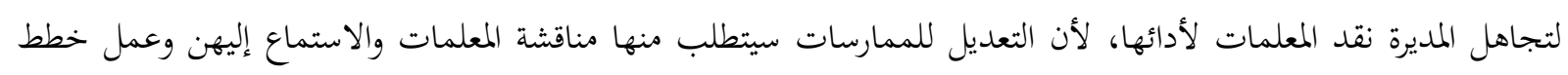

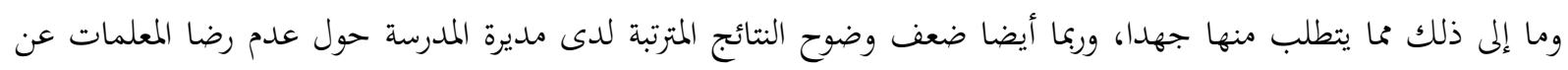

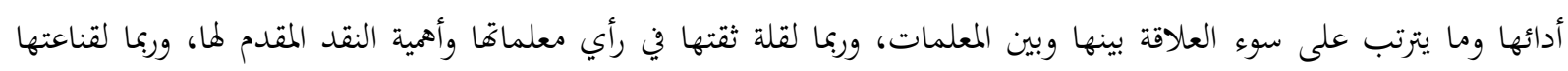

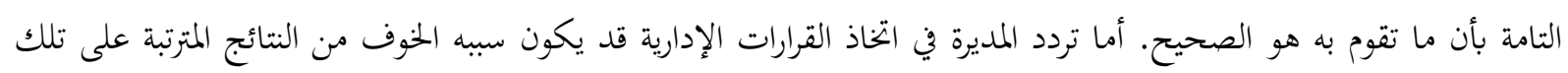

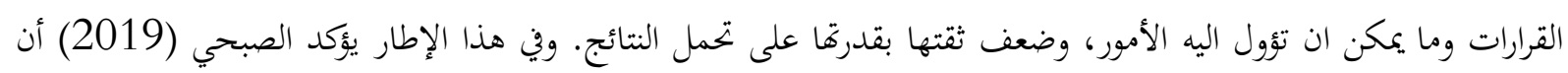

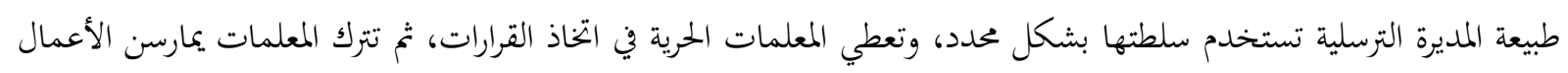

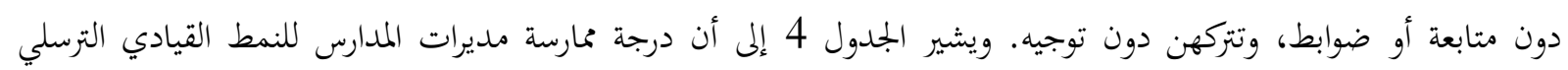

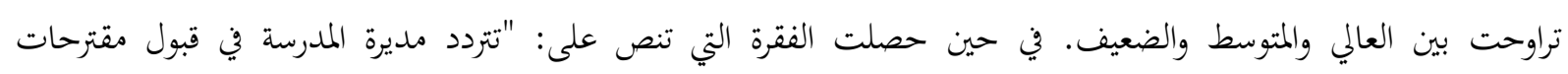

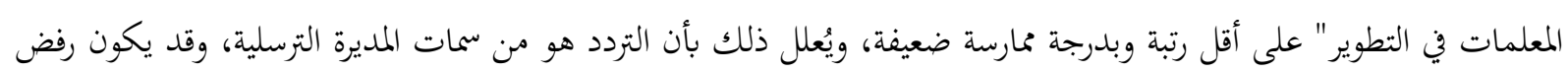

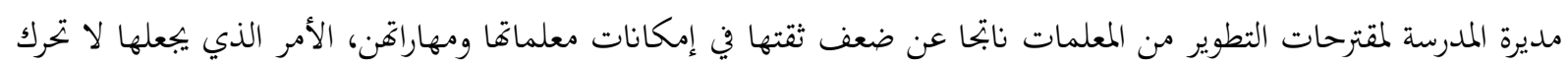

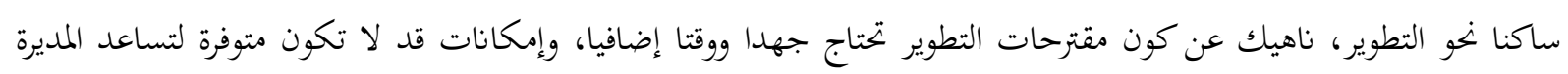

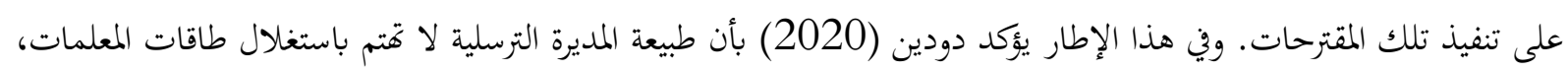
ولا تستفيد من إمكاناهن ولا تتدخل في طريقة العمل، ولا تلعب دورا في تحديد أهداف المجموعة، وهي قيادة تتخلى عن دورها الريادي، وتسير وفق الظروف.

2. ما مستوى الرضا الوظيفي لمعلمات المجال الأول في مدارس الحلقة الأولى بمحافظة شمال الباطنة التعليمية من وجهة نظرهن؟

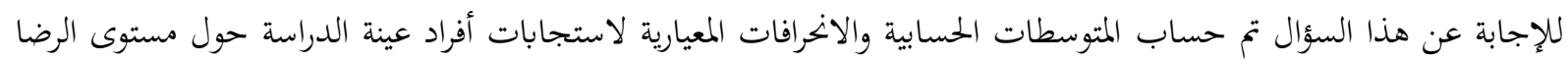
الوظيفي لمعلمات المجال الأول في مدارس الحلقة الأولى بمحافظة شمال الباطنة التعليمية لكل محور من محاور مقياس الرضا الونية الوظيفي.

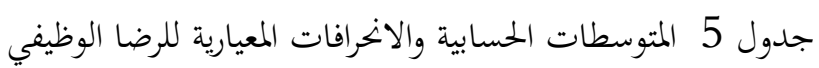

\begin{tabular}{|c|c|c|c|c|}
\hline درجة الرضا & الرتبة & الانحر اف المعياري & المتوسط الحسابي & المحاور \\
\hline عالية جدا & 1 & 0.42 & 4.62 & الرضا عن طبيعة العمل \\
\hline عالية جدا & 2 & 0.46 & 4.56 & الرضا عن زمبلات العمل \\
\hline عالية جدا & 3 & 0.71 & 4.37 & الرضا عن مديرة المدرسة \\
\hline عالية جدا & & 0.43 & 4.52 & الرضا الوظيفي العام \\
\hline
\end{tabular}

اتضح من الجدول 5 أن المتوسطات الحسابية لمحاور الرضا الوظيفي لمعلمات المجال الأول في مدارس الحلقة الأولى بمحافظة

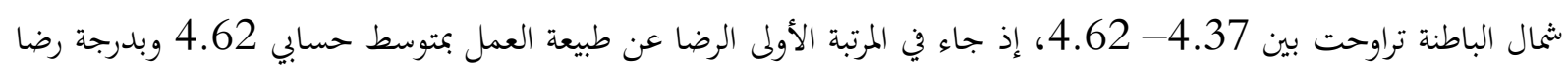


عالية جدا، وانحراف معياري 0.42. وجاء محور الرضا عن زميلات العمل في المرتبة الثانية بمتوسط حسابي 4.56 وبدرجة رضا

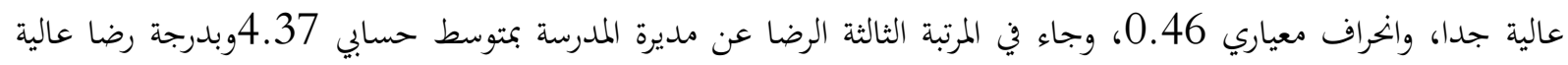
جدا، وانحراف معياري 0.71. وبلغ متوسط الرضا الوظيفي العام للمقياس

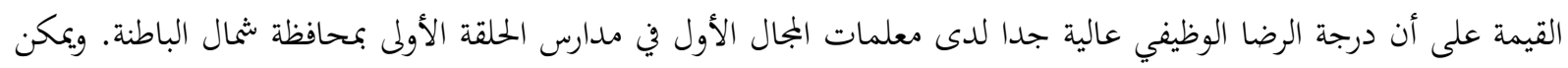
تبرير ارتفاع مستوى الرضا الوظيفي في جميع المحاور لمعلمات البمال الأول في مدارس الحلقة الأولى بمحافظة شمال الباطنة برؤية

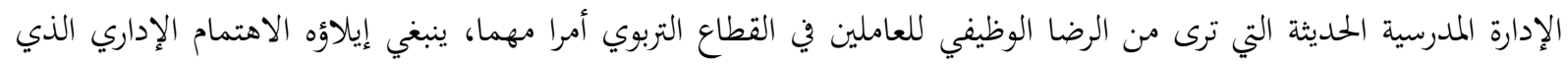

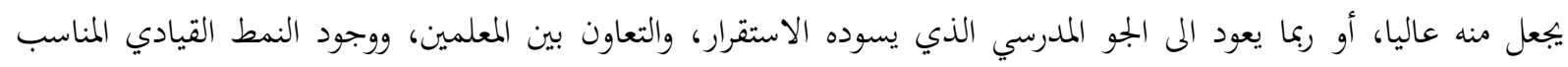

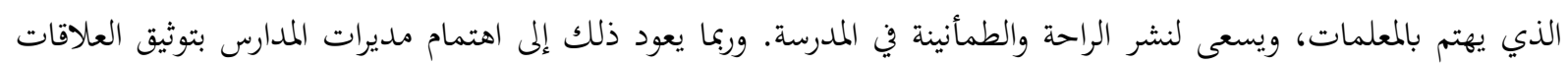

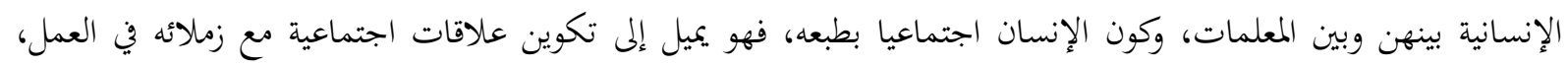

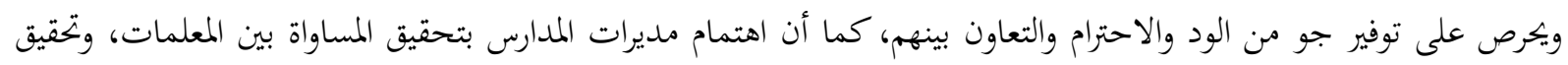

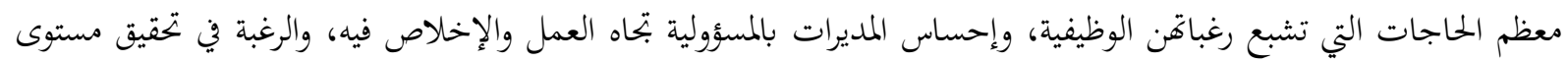

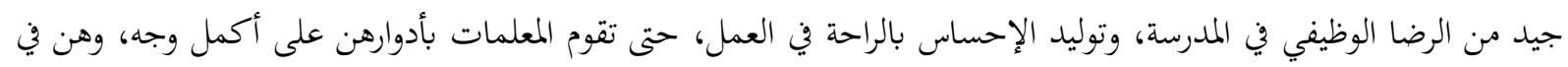

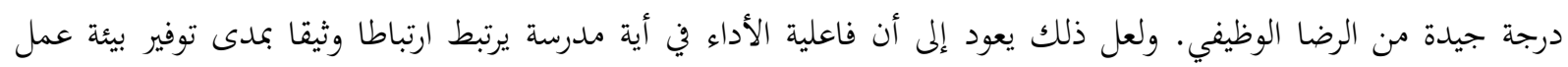

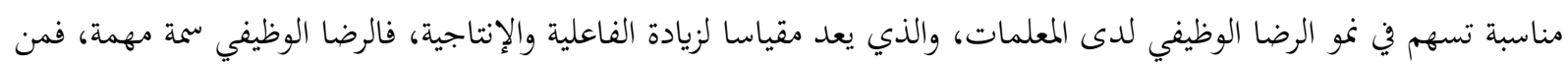

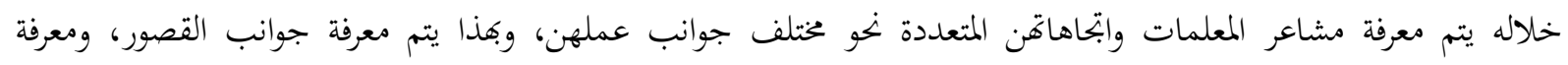

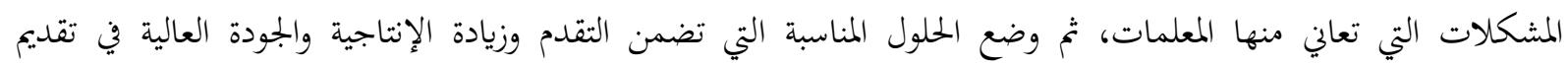

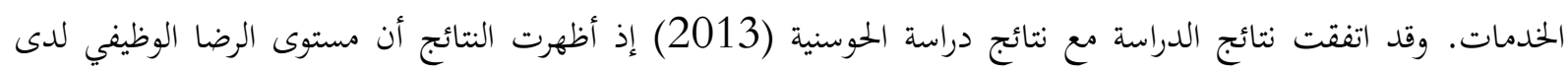

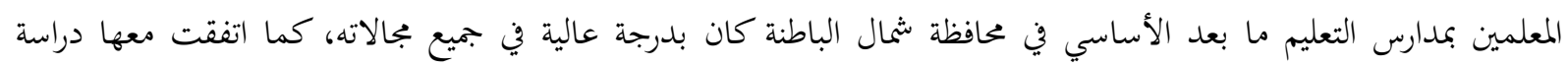
البدرية (2016) فأكدت النتائج وجود مستوى كبير من الرضا الوظيفي للمعلمين في مختلف مدارس محافظة الداخلية بسلطنة

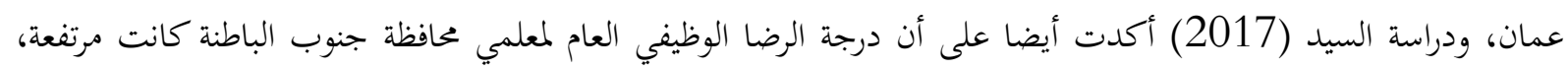

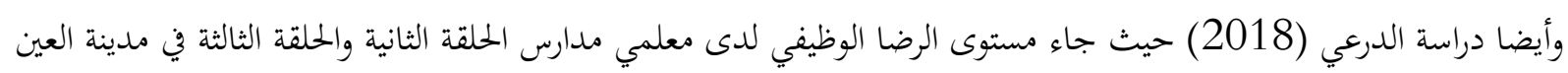

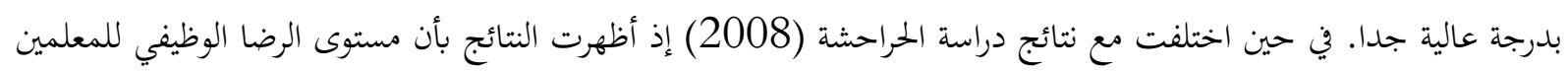
جاء بدرجة متوسطة، وأيضا دراسة الرواس (2013) أظهرت النتائج أن مستوى الرضا الوظيفي لدى المعلمين في مدارس التعليم ما بعد الأساسي كانت درجة رضا المعلمين فيها متوسطة. وللتعرف على مستوى استجابات أفراد عينة الدراسة وفقا لفقرات كل

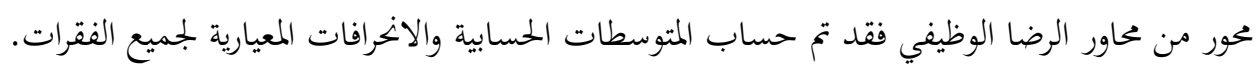

أ- الرضا عن طبيعة العمل

جدول 6 المتوسطات الحسابية والانحرافات المعيارية لفقرات الرضا عن طبيعة العمل

\begin{tabular}{|c|c|c|c|c|}
\hline 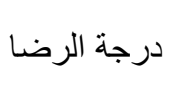 & الالنحري اف & الحسابي & الفقرات & الرتبة \\
\hline عالية جدا & 0.45 & 4.83 & أشعر أنني أنجز عملا مهما في المجتمع الدرسي. & 1 \\
\hline عالية جدا & 0.47 & 4.79 & أنشعر بالرضا عندما أنغلب على التحديات في العمل. & 2 \\
\hline عالية جدا & 0.51 & 4.72 & أستخدم أفضل الطرق لإنجاز العمل. & 3 \\
\hline عالية جدا & 0.54 & 4.67 & أحرص على التنمية المهنية الذاتية في مجال عملي. & 4 \\
\hline
\end{tabular}




\begin{tabular}{|c|c|c|c|c|}
\hline عالية جدا & 0.65 & 4.67 & أشُعر أن عملي يحقق لي ذاتي. & 5 \\
\hline عالية جدا & 0.54 & 4.66 & أنفذ المهام المطلوبة مني في الوقت المحدد. & 6 \\
\hline عالية جدا & 0.65 & 4.62 & أشعر أن عملي يقدم لي مركز ا اجتماعيا جيدا. & 7 \\
\hline عالية جدا & 0.76 & 4.54 & يتفق عملي مع ميولي المهنية. & 8 \\
\hline عالية جدا & 0.90 & 4.41 & يوفر لي عملي فرصا للإبداع والابتكار. & 9 \\
\hline ع عالية جدا & 0.77 & 4.29 & أقضي كل وقتي في أداء عملي. & 10 \\
\hline عالية جدا & 0.42 & 4.62 & & \\
\hline
\end{tabular}

اتضح من الجدول 6 أن المتوسطات الحسابية لفقرات الرضا عن طبيعة العمل تراوحت بين 4.29 -4.83، جاءت

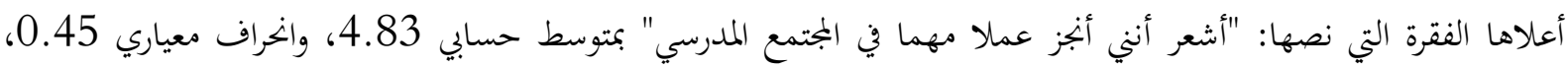
وبدرجة رضا عالية جدا، أما أقل الفقرات فقد كانت الفقرة فهي التي نصها: "أقضي كل وقتي في أداء عملي" بمتوسط حسابي بلغ 4.29، وانحراف معياري0.77، وبدرجة رضا عالية جدا. كما يتضح أن جميع فقرات هذا المحور جاءت درجة الرضا فيها بهايه عالية

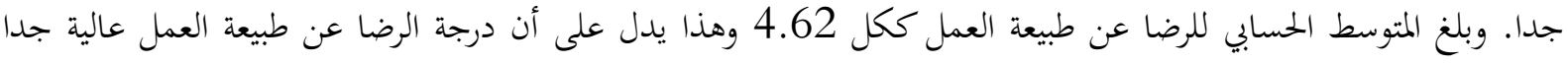
لدى معلمات المجال الأول في مدارس الحلقة الأولى بمحافظة شثمال الباطنة. وربما تعود هذه النتيجة إلى وضوح إجراءات العمل، ونسل ووضوح القوانين المنظمة له، ووجود المناخ الملائم للعمل، وتنظيم العملية التعليمية في سلطنة عمان، فهي تسير وفق خطة منظمة، لهنه

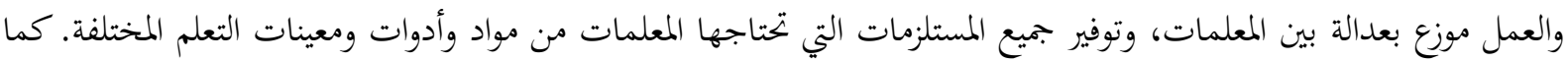

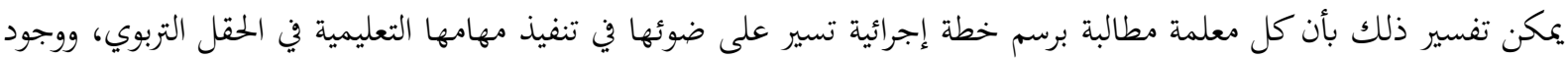
هذه الخطة قد يساعد على جعل الأمور أكثر وضوحا وإجرائية أمام هؤلاء المعلمات، وتؤدي مديرات لمهير المدارس دورا فاعلا في مراجعة هذه الخطط وفي متابعة تنفيذها، وتقديم التغذية الراجعة للمعلمات على إثر تحقق مؤشراتما. في حصلت الفقرة التي نصها:

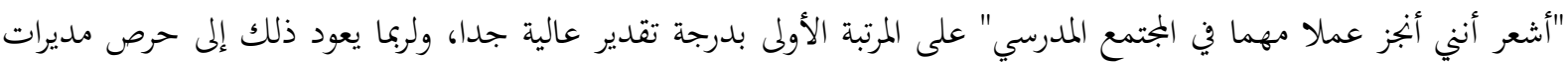

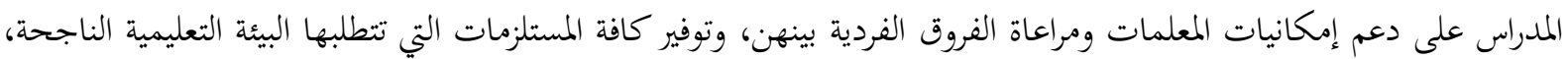
وتعزيز الجهود التي تبذل، وتقديم الحوافز المادية والمعنوية وشهادات التقدير للمعلمات المبدعات، لأنه يؤدي لزيادة الدافعية، وإنجاز العمل وتحقيق الرضا الوظيفي. في حين حصلت الفقرة التي نصها: "أقضي كل وقتي في أداء عملي" على أقل مرتبة ولكن بدرجة

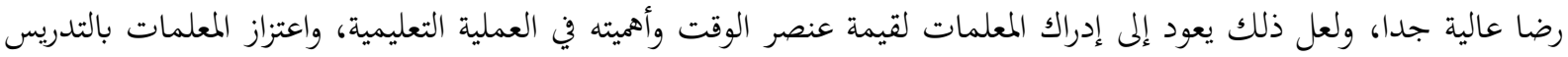

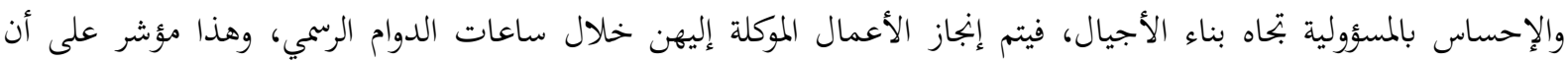
أغلب معلمات المجال الأول في محافظة شمال الباطنة يضعن جداول زيناء زمنية وظيفية تساعدهن على استغلال كل وقتهن فيما يتعلق

ب- الرضا عن مديرة المدرسة

جدول7 المتوسطات الحسابية والانخرافات المعيارية لفقرات الرضا عن مديرة المدرسة المدرسة

\begin{tabular}{|c|c|c|c|c|}
\hline درجة الرضا & المعياري & الحستوسي & الفقرات & الرتبة \\
\hline 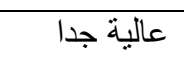 & 0.76 & 4.59 & تسعدني مشاركة مديرة المدرسة للمعلمات في المناسبات الاجتماعية. & 1 \\
\hline
\end{tabular}




\begin{tabular}{|c|c|c|c|c|}
\hline عالية جدا & 0.80 & 4.49 & تمنحني مديرة المدرسة اختيار الأسلوب المناسب لأداء عملي. & 2 \\
\hline عالية جدا & 0.76 & 4.45 & تهتم مديرة المدرسة بالمبادر ات المقترحة في المدرسة. & 3 \\
\hline عالية جدا & 0.79 & 4.45 & تقدر مديرة المدرسة عملي وجهدي. & 4 \\
\hline عالية جدا & 0.81 & 4.39 & تنمي مديرة المدرسة مهار ات التفكير الإبداعي لدى المعلمات. & 5 \\
\hline 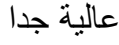 & 0.85 & 4.39 & تطلعني مديرة المدرسة على كافة المستجدات التربوية. & 6 \\
\hline عالية جدا & 0.90 & 4.32 & تساعدني مديرة المدرسة على التنمية المهنية المستمرة. & 7 \\
\hline عالية جدا & 0.97 & 4.22 & تر اعي مديرة المدرسة العدالة في التعامل مع المعلمات. & 8 \\
\hline 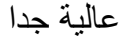 & 0.92 & 4.22 & تتقبل مديرة المدرسة النق البناء الصادر مني. & 9 \\
\hline 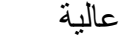 & 0.99 & 4.19 & تزودني مديرة المدرسة بالتجهيز ات الداعمة للتعلم. & 10 \\
\hline عالية جدا & 0.71 & 4.37 & الرضا العام عن مديرة المدرسة & \\
\hline
\end{tabular}

كشف الجدول 7 عن أن المتوسطات الحسابية لفقرات الرضاعن مديرة المدرسة تراوحت بين 4.19-4.59 جاءت

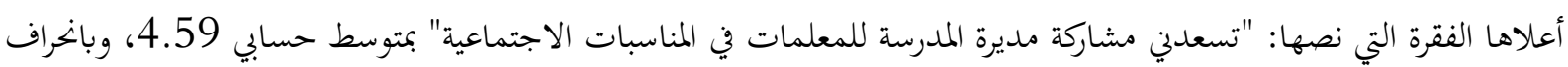

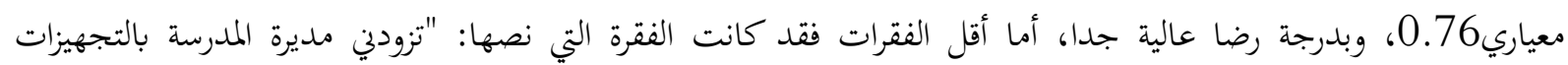

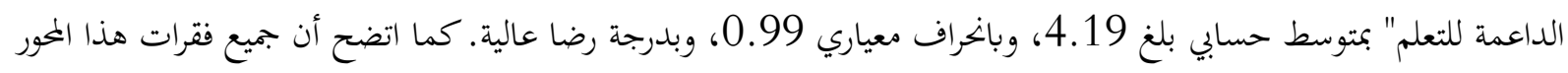

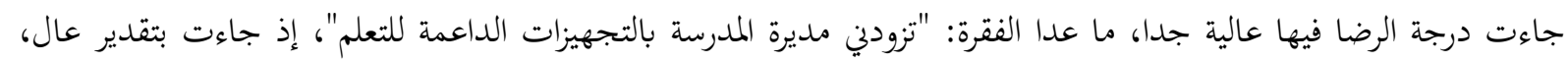

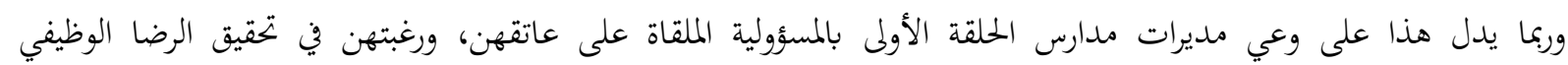

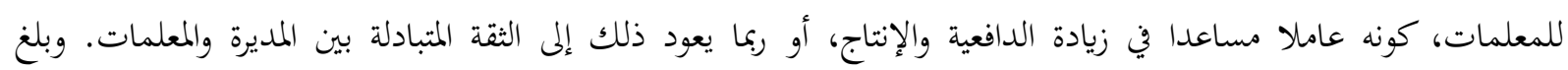
المتوسط الحسابي للرضا عن مديرة المدرسة ككل 4.37، وبهذا فإن درجة الرضا عن مديرة المدرسة عالية جدا لدى معلى معلمات المجال

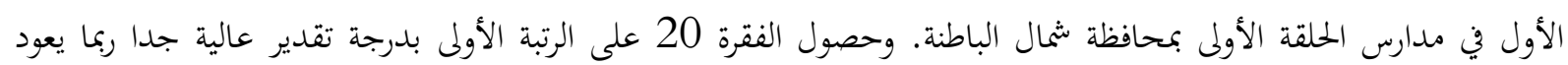

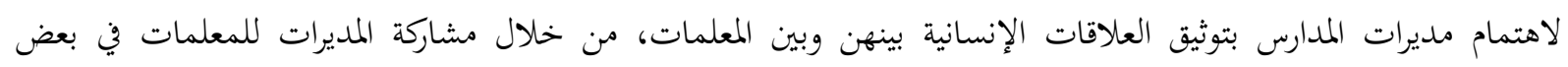

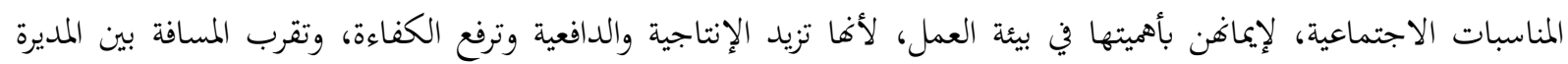

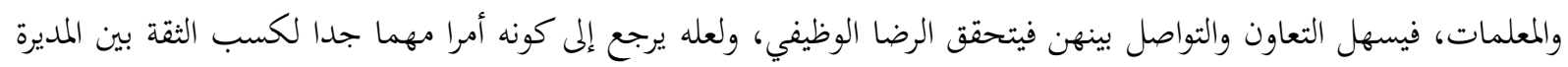

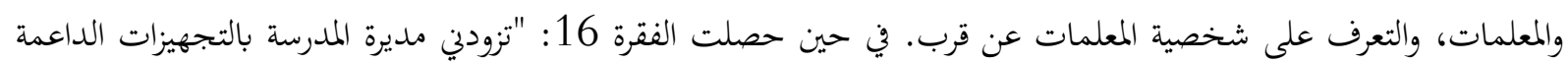

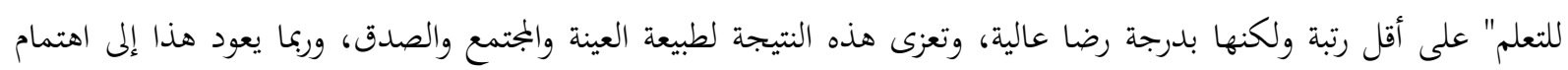

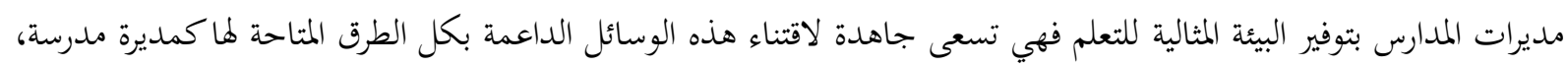

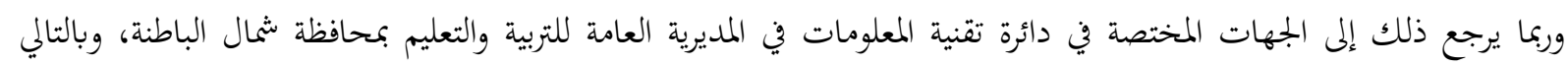
فالمديرات يتحركن في هذا الإطار، كما أن لديهن بعض الصلاحيات نحو مخاطبة بعض الشركات الشركات المتعاونة لخدمة المجتمع، لتوفير

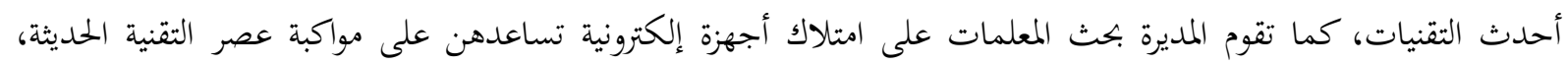

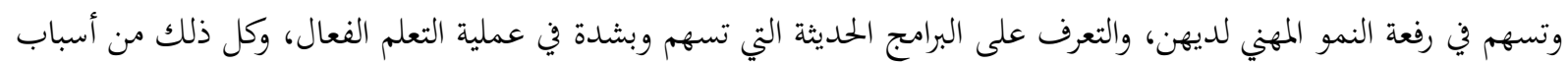
تكوين درجة عالية من مستوى الرضا الوظيفي للمعلمات نهو مديرة المدرسة. 
ث- الرضا عن زميلات العمل

جدول8 المتوسطات الحسابية والانحافات المعيارية لفقرات الرضا عن زميلات العمل

\begin{tabular}{|c|c|c|c|c|}
\hline 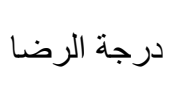 & 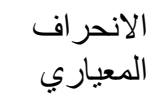 & 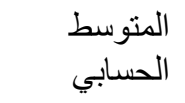 & 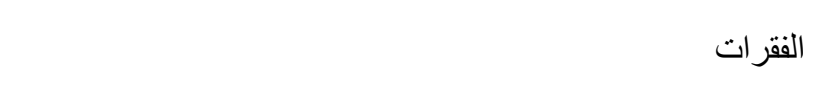 & 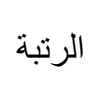 \\
\hline 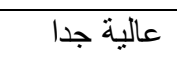 & 0.47 & 4.79 & أثشعر بالسعادة عندما أتعاون مع زميلاتي المعلمات. & 1 \\
\hline عالية جد & 0.43 & 4.78 & أنشئ علاقات طيبة مع زميلاتي في المدرسة. & 2 \\
\hline 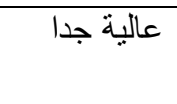 & 0.58 & 4.66 & مدرستي. أُشارك زميلاتي في حل المشكلات و التغلب على التحديات في & 3 \\
\hline عالية جدا & 0.63 & 4.65 & في بيئة العمل. الانطاع الإيجابي لزميلاتي المعلمات عن التطوير و التغيير & 4 \\
\hline عالية جدا & 0.65 & 4.62 & تتظر زميلاتي المعلمات نظرة إيجابية لعملي في المدرسة. & 5 \\
\hline عالية جدا & 0.76 & 4.56 & توجهني زميلاتي المعلمات على الإخلاص في عملي. & 6 \\
\hline عالية جدا & 0.64 & 4.56 & تسود روح التنافس بيني وبين زميلاتي المعلمات. & 7 \\
\hline عالية جدا & 0.81 & 4.49 & تسود روح التعاون بين المعلمات في مدرستي. & 8 \\
\hline عالية جدا & 0.71 & 4.47 & تلقى أفكاري اهتماما من قبل زميلاتي. & 9 \\
\hline عالية & 0.97 & 4.07 & تثجعني زميلاتي المعلمات على إكمال دراستي العليا. & 10 \\
\hline عالية جدا & 0.46 & 4.56 & ميلات العمل ككل & الرضا \\
\hline
\end{tabular}

بيّن الجدول 8 أن المتوسطات الحسابية لفقرات الرضا عن زميلات العمل تراوحت بين 4.07-49.79 جاءت أعلاها

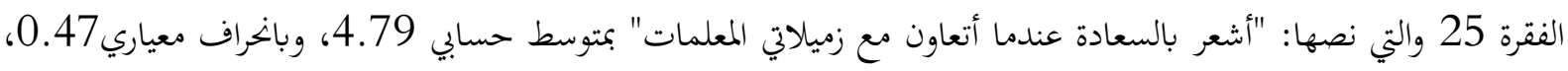
وبدرجة رضا عالية جدا، أما أقلها كانت الفقرة27 والتي نصها: "تشجعني زميلاتي المعلمات على إكمال دراستي العليا" بمتوسط

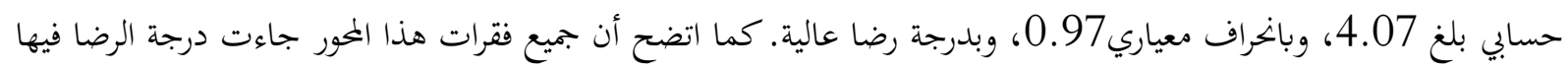

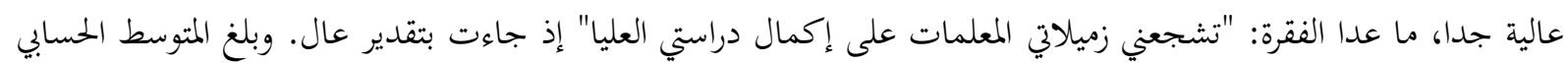

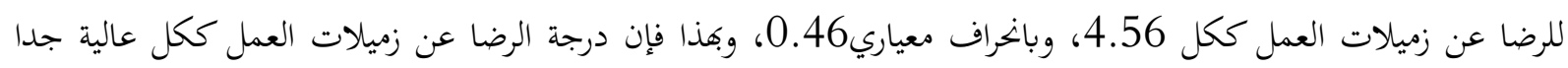

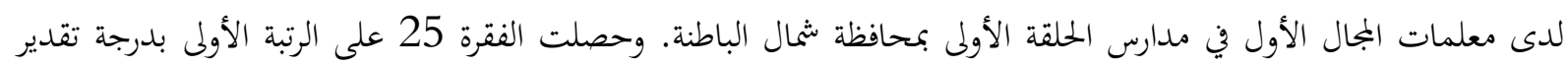

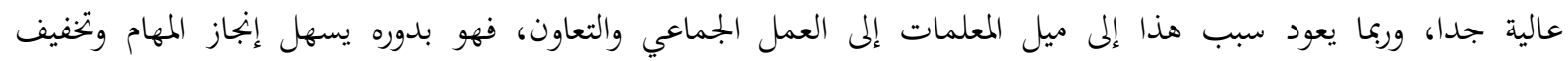

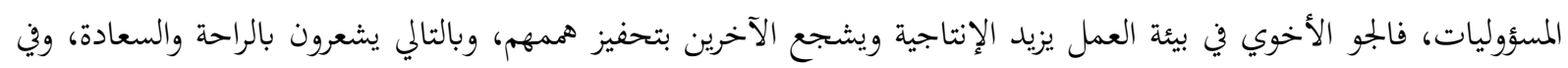

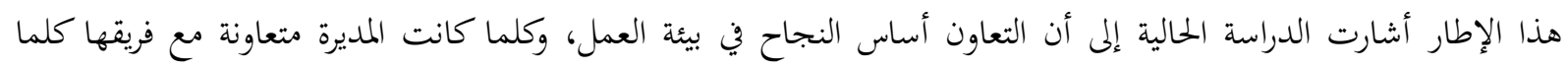
حققت النجاح والسعادة، وكذلك بالنسبة للمعلمات فالتعاون مع زميلات العمل يحافظ على الإنتاجية سواء من الناحية الاجتماعية أو النفسية أو الوظيفية، فالتعاون الإيجابي يضفي السعادة والمرح والسرور في نفوس المعلمات، وكل ذلك ينكات ينعكس إيجابا على مستوى الرضا الوظيفي لدى المعلمات. 
3. هل توجد علاقة ارتباطية بين الأنماط القيادية لدى مديرات مدارس الحلقة الأولى والرضا الوظيفي لمعلمات البمال الأول في

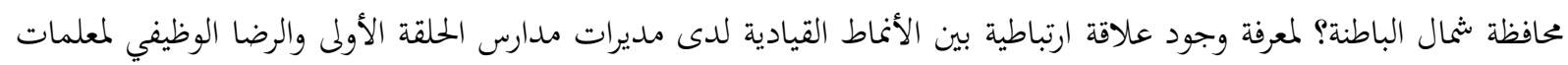

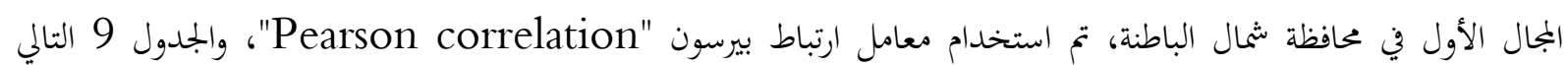
يوضح هذه النتائج. قيم معامل ارتباط بيرسون بين الأنماط القيادية والرضا الوظيفي

\begin{tabular}{|c|c|}
\hline الرضا الوظيفي & أنماط القيادة \\
\hline $0.61^{*}$ & النمط القيادي الديمقراطي \\
\hline$-0.14 *$ & النمط القيادي الأوتوقراطي \\
\hline-0.10 & النمط القيادي الترسلي \\
\hline
\end{tabular}

(د 2 (ال إحصائيا عند مستوى (20.05)

اتضح من الجدول 9 وجود علاقة طردية متوسطة دالة إحصائيا بين النمط القيادي الديمقراطي والرضا الوظيفي، حيث بلغ

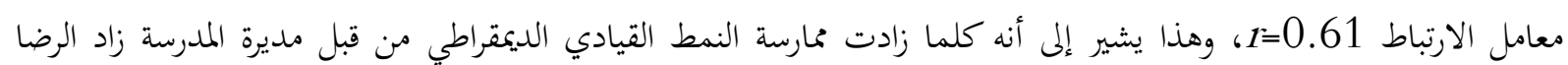
الوظيفي لدى المعلمات. كما أشارت النتائج أيضا إلى وجود علاقة سالبة ضعيفة بين النمط القيادي الأوتوقراطي والرضا الوظيل الوظيفي حيث بلغ معامل الارتباط

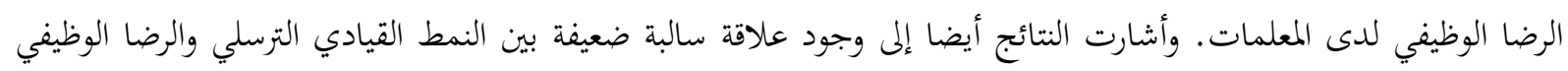
حيث بلغ معامل الارتباط (0.10-

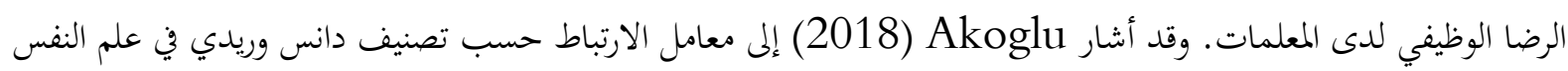
نتكون العلاقة متازة (1-1+)، ومن (0.7 Dancey and Reidy (Psychology)

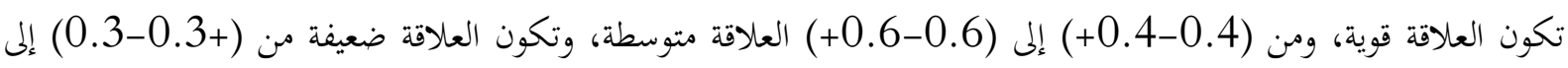

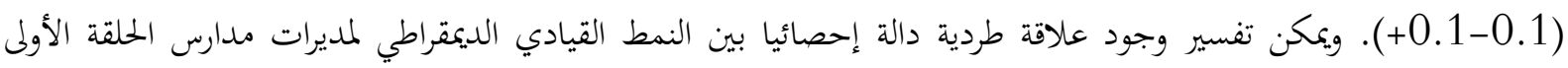

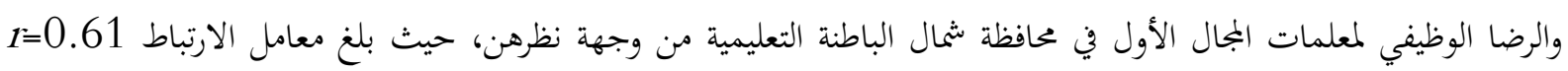

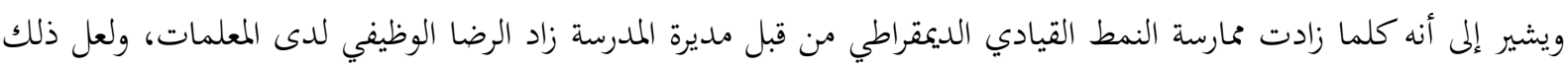

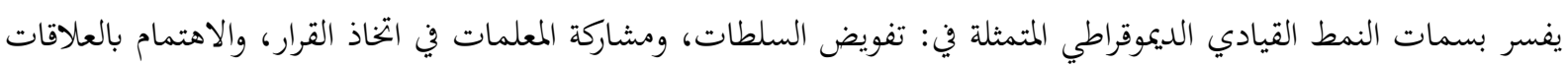

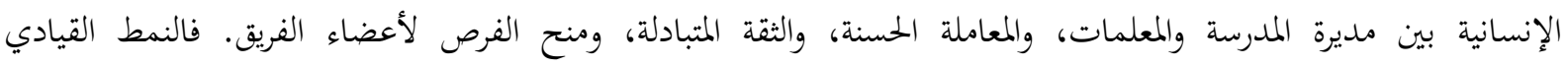

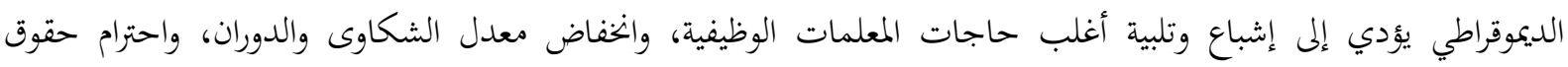

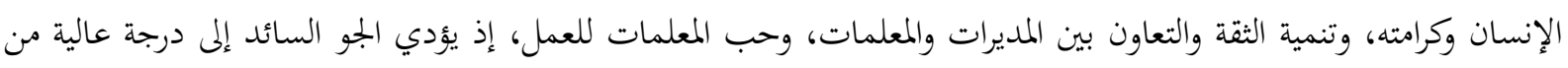

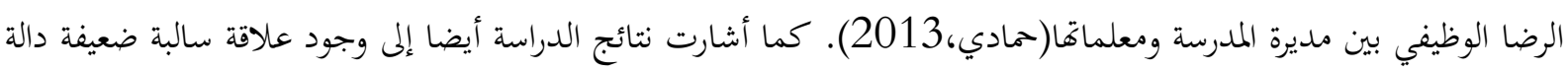

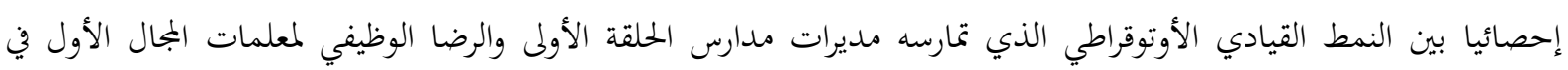

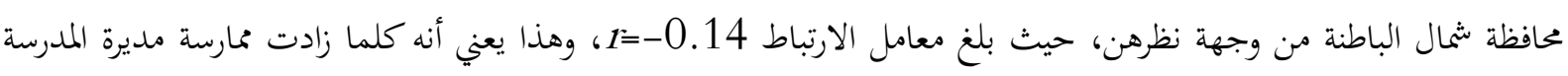

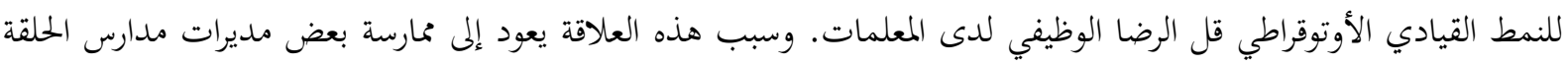

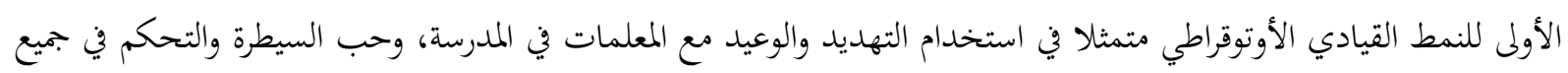
الأمور بالمدرسة، وضعف الاهتمام بتفويض بعض الصلاحيات للمعلمات بالمدرسة، وضعف العلاقات الإنسانية أحيانا، وربما قلة الاحترام المتبادل بين مديرة المدرسة والمعلمات، وكل ذلك ينعكس سلبا على سلوك المعلمات، ويكون شعورهن سلبيا بتحاه مديرة المدرسة، وينتج عنه ضعف مستوى الرضا الوظيفي، مما ينعكس سلبا على أداء المعلمات في مجال عملهن بالمدرسة. وأشارت نتائج 
الدراسة أيضا إلى وجود علاقة سالبة ضعيفة بين النمط القيادي الترسلي الذي تمارسه مديرات مدارس الحلقة الأولى والرضا الوظيفي لمعلمات المجال الأول في محافظة شمال الباطنة من وجهة نظرهن حيث بلغ معامل الارتباط

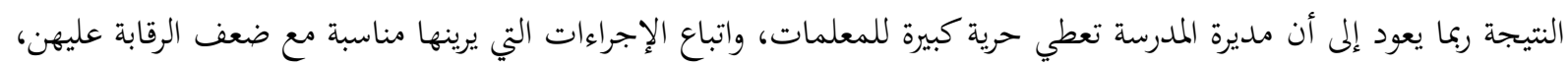

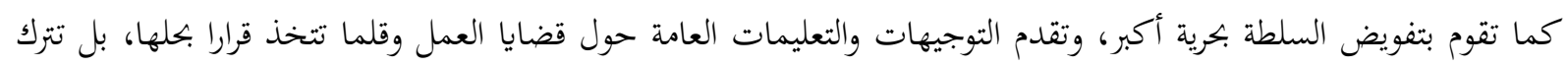

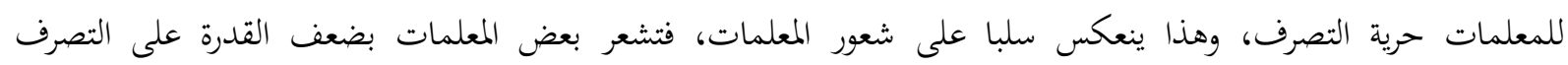

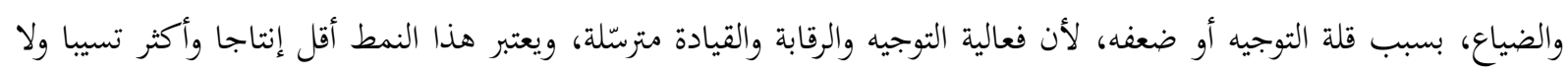

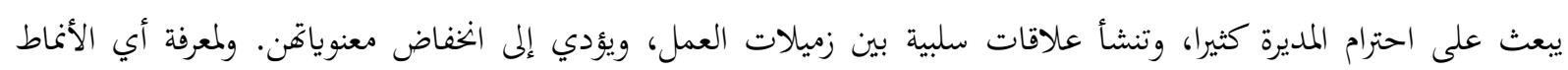

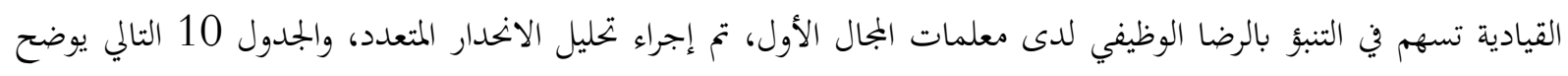
هذه النتائج.

جدول 10 ملخص نتائج تحليل تباين الانحدار الخطي المتعدد للتنبؤ بمستوى الرضا الوظيفي من خلال الأنماط القيادية

\begin{tabular}{|c|c|c|c|c|c|c|}
\hline قابثة & $R^{2}$ & الاحتمالية & الثحسة"تة & معامل الاتحدار (Beta) & غير المعياري(B) معامل الاتحدار & ألمدرسية القيادة \\
\hline \multirow[t]{3}{*}{2.44} & \multirow[t]{3}{*}{0.38} & 0.000 & 13.79 & 0.63 & 0.45 & الديموقر اطي \\
\hline & & 0.37 & 0.90 & 0.07 & 0.03 & الأوتوقر اطي \\
\hline & & 0.87 & -0.16 & -0.01 & 0.01 & الترسلي \\
\hline
\end{tabular}

اتضح من خلال الجدول 10 أنه يمكن التنبؤ بالرضا الوظيفي لدى معلمات المجال الأول بمحافظة شمال الباطنة من خلال

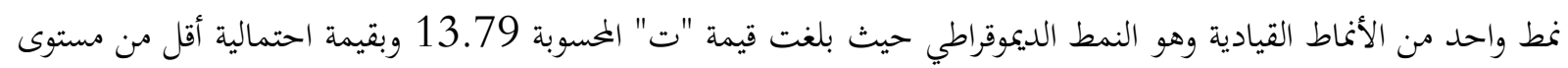

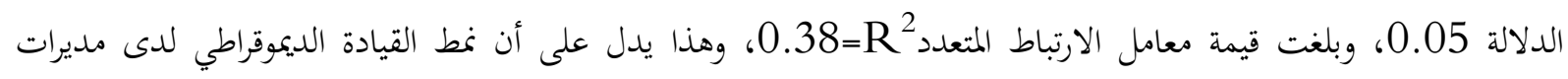
مدارس الحلقة الأولى يفسر ما نسبته 38\% من التغيرات الحادثة في الرضا الوظيفي لدى معلمات المجال الأول، أما النسبة المتبقية

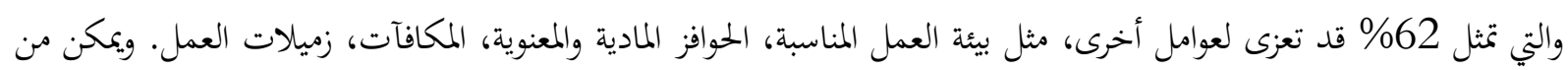

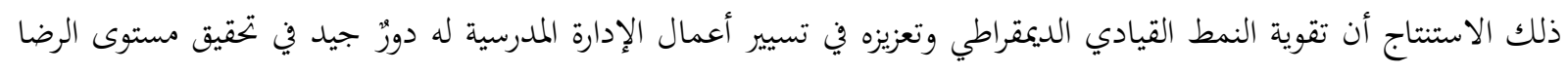

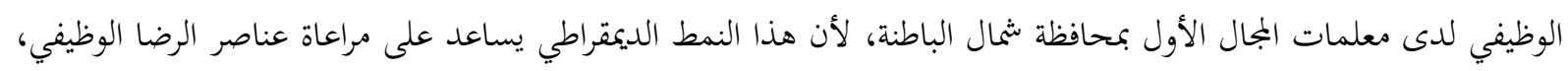

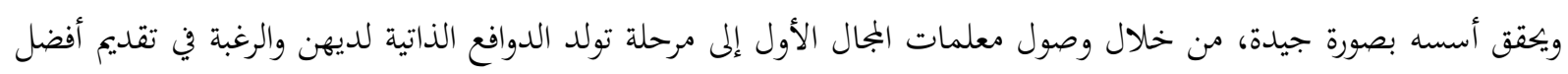

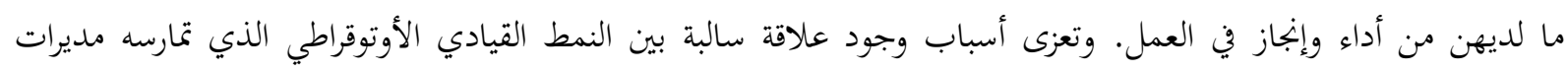

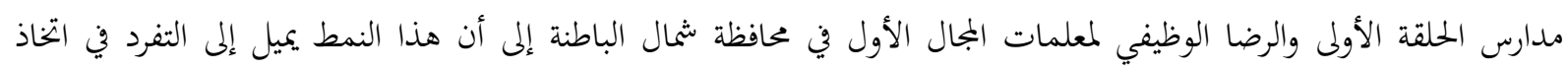

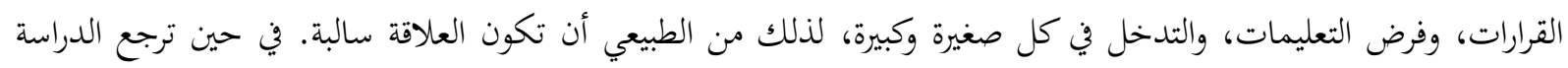

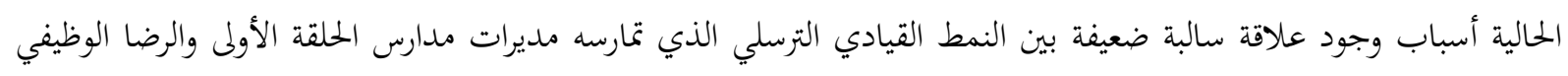

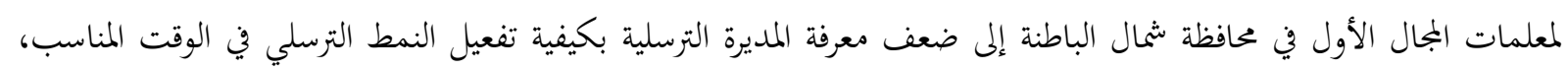

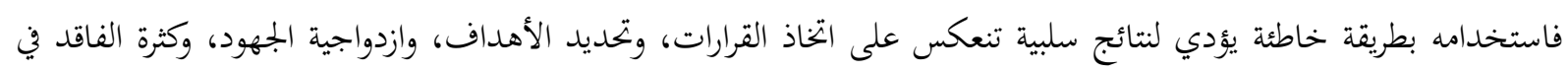

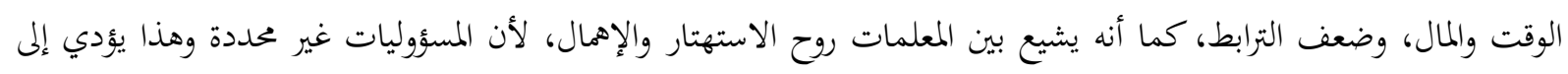

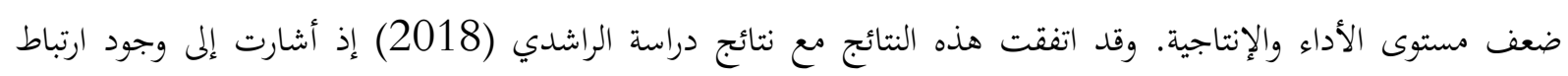

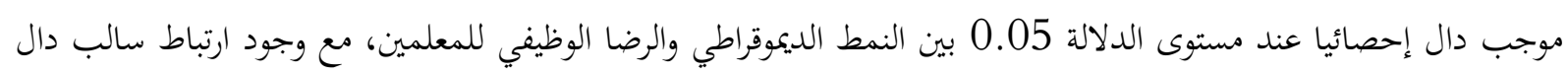
إحصائيا عند مستوى الدلالة 0.05 للنمط الأوتوقراطي، كما أظهرت نتائج دراسة الحراحشة (2008) بأن هناك علدين علاقة إيجابية 
بين النمط القيادي ومستوى الرضا الوظيفي للمعلمين. وأيضا اتفقت مع دراسة الصبحي (2019) بوجود علاقة ارتباطية موجبة دالة إحصائيا بين ممارسة مديري المدارس للنمط الديموقراطي ومستوى الرضا الوظيفي للمعلمين.

\section{التوصيات}

1. الحفاظ على مستوى ممارسة فاعلة للنمط القيادي الديمقراطي لدى مديرات مدارس الحلقة الأولى بمحافظة شمال الباطنة، لما له

$$
\text { من أهمية في تحقيق مستوى جيد من الرضا الوظيفي. }
$$

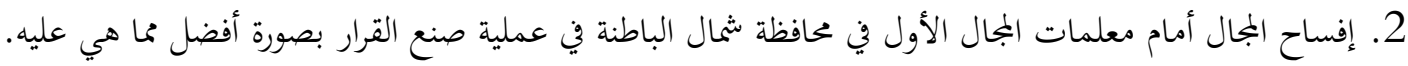

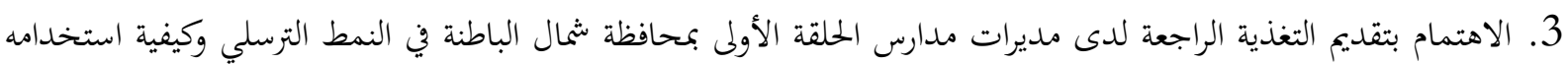

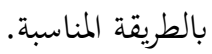

4. الحفاظ على مستوى الرضا الوظيفي العالي لدى معلمات المجال الأول بمحافظة شمال الباطنة، لما له من دور في تحقيق أهداف

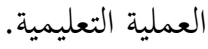

5. تعزيز مديرات مدارس الحلقة الأولى بمحافظة شمال الباطنة، لينعكس ذلك بدوره على المعلمات، وبالتالي تحقيق الرضا الوظيفي

6. زيادة الاهتمام بالجانب الإنساني بين معلمات المجال الأول في محافظة شمال الباطنة، ومديرات مدارس الحلقة الأولى.

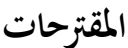

1. إجراء مزيد من البحوث لدراسة الرضا الوظيفي، لرفع مستواه عند معلمات المجال الأول.

2. إجراء دراسات مماثلة للدراسة الحالية، للتعرف على العوامل المؤثرة في الرضا الوظيفي لمعلمات المجال الأول.

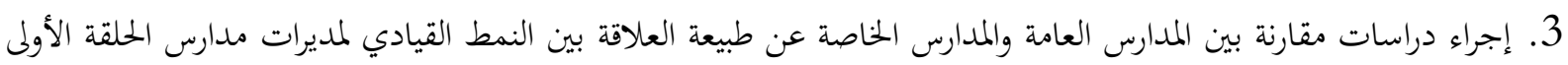

$$
\text { ومستوى الرضا الوظيفي لمعلمات المجال الأول. }
$$

4. عقد دورات تدريبية لمديرات مدارس الحلقة الأولى بمحافظة شمال الباطنة، لتدريبهن على كيفية استخدام النمط القيادي الفاعل

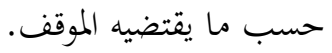

5. إجراء مزيد من البحوث لدراسة أثر النمط القيادي الترسلي والأوتوقراطي في تحقيق الرضا الوظيفي. 


\section{مراجع الدراسة ومصادرها}

أبو طاحون، أمل لطفي. (2012). القيادة التربوية الفاعلة. أمواج للطباعة والنشر والتوزيع. أبو عساف، مؤيد يوسف، والمرعي، هيثم عبد الله. (2019). التطبيقات العلمية في إدارة الموارد البشرية بالمؤسسات العامة والخاصة. دار أبجد للنشر والتوزيع.

أشتيتات، سامح محمد. (2017). النمط الإداري لمدراء المدارس وعلاقته بالأمن الوظيفي لدى المعلمين في محافظة إربد. مجلة

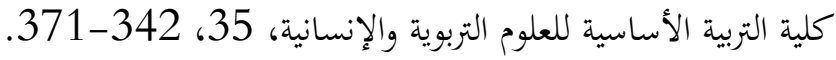

البارودي، منال أحمد. (2015). الرضا الوظيفي وفن التعامل مع الرؤساء والمرؤوسين. المجموعة العربية للتدريب والنشر. بشير، يوسف حسن. (2015). أثر الرضا الوظيفي على أداء العاملين في مؤسسات التعليم العالي [أطروحة دكتوراه غير الوراء منشورة]. جامعة السودان، السودان. التربية والتعليم تواصل جهودها الرامية إلى تجـويد عناصر العملية التعليمية. 29 نوفمبر.2019. جريدة عمان https://www.omandaily.om/?p=748340.

جامعة السلطان قابوس. (2014، مايو). ندوة التعليم في عمان والخليج العربي. مسترجع من https://www.squ.edu.om/osc-ar

الجساسية، بدرية مبارك. (2016). الأنماط القيادية لمديري مدارس التعليم ما بعد الأساسي في سلطنة عمان وفقا لنظرية المسار والهدف وأثرها في الرضا الوظيفي للمعلمين [رسالة ماجستير غير منشورة]. جامعة صحار . سلطنة عمان. حافظ، عبد الناصر. (2015). الأنماط القيادية الطريق لبناء الميزة التنافسية المستدامة. دار غيداء للنشر والتوزيع.

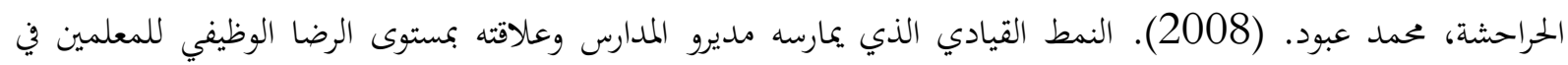
مديرية التربية والتعليم في محافظة الطفيلة. بجلة جامعة دمشق 24. الحريري، رافدة، وعبد الحميد، فاتن، والوادي، حسن. (2017). أساسيات ومهارات البحث التربوي والإجرائي. دار أبجد للنشر فئر

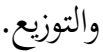

حمادي، عدي عطا. (2013). القيادة الإدارية الحديثة في إستراتيجية التنمية. دار البداية.

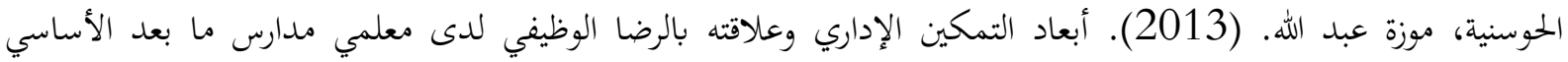
بمحافظة شمال الباطنة بسلطنة عمان [رسالة ماجستير غير منشورة] . جامعة نزوى، سلطنة عمان.

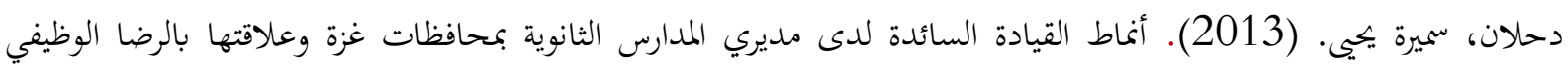
للمعلمين [رسالة ماجستير غير منشورة]. جامعة الأزهر، غزة. لماطئ. الدرعي، حميد راشد. (2018). أثر القيادة الديمقراطية على الرضا الوظيفي لدى مدارس مدينة العين بدولة الإمارات العربية المتحدة [رسالة ماجستير غير منشورة]. جامعة صحار، سلطنة عمان. دودين، أحمد يوسف. (2020). إدارة التغيير والتطوير التنظيمي. دار اليازور العلمية. الدوسري، حسن مرضي. (2013). الأنماط القيادية وعلاقتها بالرضا الوظيفي في كلية التقنية بالخرج من وجهة نظر المورئ الموظفين [رسالة ماجستير غير منشورة]. جامعة نايف العربية للعلوم الأمنية، المملكة العربية السعودية. 
الراشدي، سعيد راشد. (2018). الأنماط الإدارية السائدة لدى مدراء مدارس التعليم ما بعد الأساسي للصفين (11-12)

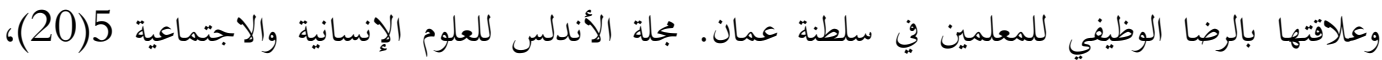

.228-181

الرواس، منى عبد السلام. (2013). الرضا الوظيفي لدى معلمي مدارس التعليم ما بعد الأساسي بولاية صلالة من وجهة نظرهم [رسالة ماجستير غير منشورة] كلية الآداب والعلوم التطبيقية، جامعة ظفار، سلطنة عمان.

السكارنة، بلال خلف. (2010). القيادة الإدارية الفعالة. دار المسيرة للنشر والتوزيع.

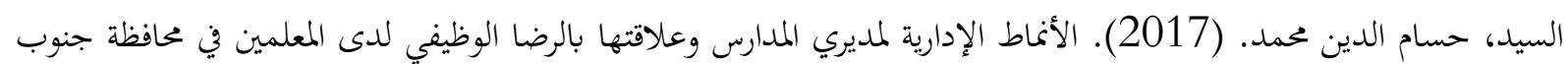

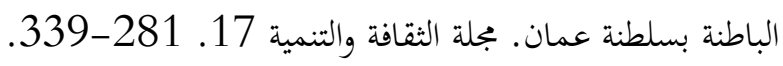

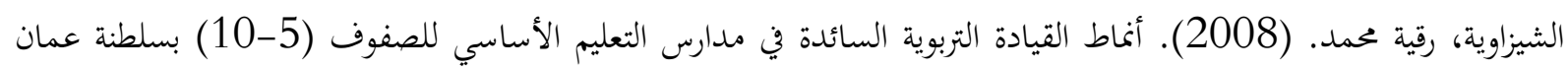

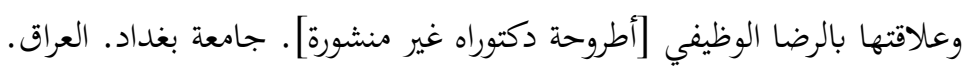

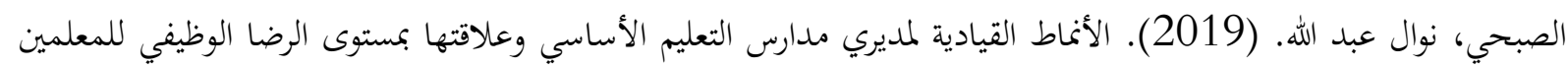
في مدينة أبو ظبي [رسالة ماجستير غير منشورة] . جامعة صحار، سلطنة عمان.

الغامدي، علي محمد. (2010). نمط القيادة التربوية لدى مديري المدارس في المدينة المنورة كما يتصوره المعلمون. مجلة العلوم

$$
\text { التربوية والنفسية. 11(4)، 107-135. }
$$

الغزو، فاتن عوض. (2010). القيادة والاشراف الإداري. دار أسامة للنشر والتوزيع.

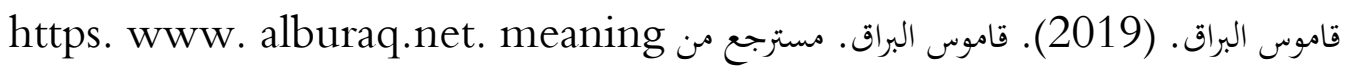

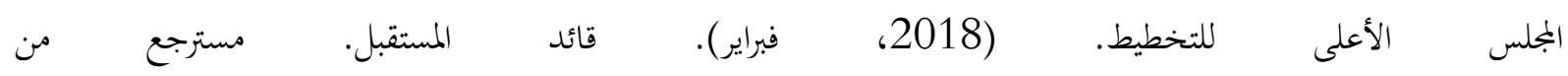
https://www.omandaily.om/?p=566706 مجلس الشورى. (2015). واقع المعلم في سلطنة عمان. مسقط. سلطنة عمان. المحمدي، سعد علي. (2019). إدارة الموارد البشرية، رؤية إستراتيجية ومنهجية متكاملة. دار اليازوري العلمية. محمد، مصطفى. (2018). الرضا الوظيفي وأثره في تطوير الأداء. دار ابن النفيس للنشر والتوزيع.

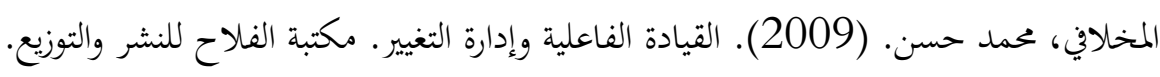
المكاوي، عاطف عبد الله. (2013). القيادة الإدارية. مؤسسة طيبة للنشر والتوزيع.

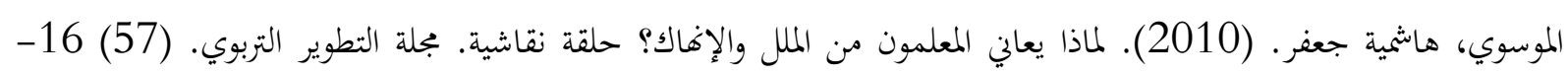
21 هاشم، عادل عبد الرزاق. (2019). القيادة وعلاقتها بالرضا الوظيفي. دار اليازوري العلمية للنشر والتوزيع. وزارة التربية والتعليم. (2008). دليل نظام تطوير الأداء المدرسي. مسقط. سلطنة عمان. وزارة التربية والتعليم. (2019). الكتاب السنوي للإحصاءات التعليمية (49). (49). سلطنة عمان.

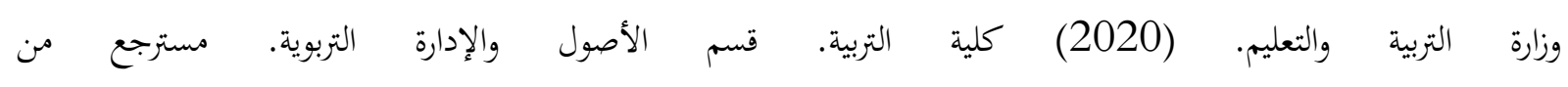
https://www.squ.edu.om/education-ar

يامنة، إسماعلي، وخير الدين، بن خرور. (2019). الأبعاد المحددة للعلاقات الإنسانية في الإدارة المدرسية. دار اليازوري العلمية. Akoglu. H. (2018). User's guide to correlation coefficients. Turkish Journal of Emergency Medicine. (18)91-93. 
Hancott, D. (2016). Leadership is what the importance of vision, integrity, and developing others? Lulu publishing services.

Munir, H. \& Iqbal, M. (2018). A study of relationship between leadership styles of principals and Job Satisfaction of Teachers in Colleges for woman. Bulletin of Education and Research. 40(2) 65-78.

Osbourne, R.(2015). Job Satisfaction. Nova Science Publishers.

Rao, B., \& Sridhar, D. (2003). Job Satisfaction of School Teachers. Discovery Publishing House.

Taber,K.(2016).The use of Cronbach,s alpha when developing and reporting research instruments in science education. Research in Science Education,48(6),1273-1296. 